\title{
Romance and Croatian in Contact: Non-Clitic Auxiliaries in Istro-Romanian
}

\author{
Adina Dragomirescu ${ }^{1,2}$ and Alexandru Nicolae 1,2,*(D) \\ 1 “Iorgu Iordan - Al. Rosetti" Institute of Linguistics, 050711 Bucharest, Romania; \\ adina.dragomirescu@unibuc.ro \\ 2 Department of Linguistics, Faculty of Letters, University of Bucharest, 010017 Bucharest, Romania \\ * Correspondence: alexandru.nicolae@unibuc.ro
}

\section{check for} updates

Citation: Dragomirescu, Adina, and Alexandru Nicolae. 2021. Romance and Croatian in Contact: Non-Clitic Auxiliaries in Istro-Romanian. Languages 6: 187. https://doi.org/ 10.3390/languages6040187

Academic Editors: Ángel Gallego, Bruno Camus, Ricardo Etxepare, Iván Ortega-Santos, Diego Pescarini, Francesc Roca, Juan Uriagereka and Greta Mazzaggio

Received: 12 July 2021

Accepted: 5 November 2021

Published: 13 November 2021

Publisher's Note: MDPI stays neutral with regard to jurisdictional claims in published maps and institutional affiliations.

Copyright: (c) 2021 by the authors. Licensee MDPI, Basel, Switzerland. This article is an open access article distributed under the terms and conditions of the Creative Commons Attribution (CC BY) license (https:// creativecommons.org/licenses/by/ $4.0 /$ )

\begin{abstract}
This paper focuses on Istro-Romanian and argues that the TAM auxiliaries of this variety are not morphophonological clitics. This analysis is supported by the existence of several empirical phenomena (auxiliary-licensed VP-ellipsis, scrambling, and interpolation), some not found in modern Romance, others very rare in modern Romance. This property of Istro-Romanian auxiliary verbs accounts, in conjunction with other features of this variety (e.g., the availability of C-oriented and I-oriented pronominal clitics), for the massive variation in the word order of pronominal clitics, auxiliaries, and the lexical verb found in the Istro-Romanian sentential core. An endangered Romance variety spoken in Istria and in the diaspora, historically related to (Daco-)Romanian, Istro-Romanian has been in contact with Croatian since the settlement of Istro-Romanians in the Istrian peninsula. As some of the Istro-Romanian features and phenomena are found both in Croatian and in old Romanian, it appears that contact with Croatian acts as a catalyst of structural convergence engendering the retention of an archaic property of Istro-Romanian auxiliaries: a lower position on the grammaticalization cline, closer to the full word status of their etyma.
\end{abstract}

Keywords: auxiliary; VP-ellipsis; verb movement; language contact; Istro-Romanian; old Romanian; Croatian; convergence

\section{Introduction}

\subsection{Background}

Istro-Romanian is an endangered Romance variety spoken in Istria, Croatia, with about 200 speakers at present (cf. Filipi 2002; Vrzić and Doričić 2014), plus émigré speakers in the New York area (Maiden 2016, p. 91). Traditionally considered to be one of the sub-Danubian "historical dialects" of Romanian (alongside Aromanian and MeglenoRomanian), Istro-Romanian ${ }^{1}$ displays two tendencies in its syntax: (i) on the one hand, Istro-Romanian displays a series of Romance archaic features, also found in old Romanian (which have been taken to mirror the shape of the language at the moment of the dialectal split, presumed to have finished around the 14th century); (ii) on the other, we observe the influence on the syntax of Istro-Romanian of Croatian ${ }^{2}$ (see Kovačec 1966, 1968) and, to a much more limited extent, of Northern Italian dialects, Croatian-Istro-Romanian bilingualism being the norm in the area. While a comprehensive grammar/syntax of Istro-Romanian is not available at present, there exist partial descriptions of this linguistic dialect (Popovici 1914; Puşcariu 1926; Coteanu 1957; Kovačec 1971, 1984, 1998; Caragiu Marioțeanu 1975; Sârbu and Frățilă 1998; Hurren 1999; Zegrean 2012; Giusti and Zegrean 2015; Maiden 2016) which offer significant details and insights into its structure. It is also important to mention that 'old Romanian' refers to the timespan comprised between the beginning of the 16th c. and the year 1780; the first written attestations of Romanian date back to the beginning of the 16th c.: Neacșu's Letter (1521), the first non-translated text written in Romanian, and The Hurmuzaki Book of Psalms (1500/1510), the first translation of a foreign (Old Church Slavonic) text in Romanian. See Timotin (2016) for more details on 
the periodization of Romanian. Notably, the dialectal split took place prior to the earliest written attestations of Romanian.

\subsection{Aim of the Paper and Methodology}

The verbal nexus of Istro-Romanian is characterized by massive variation, displaying numerous distinct word order patterns of pronominal clitics, auxiliaries, and the lexical verb-all of them found across Romance, but not at the same time in the same variety. Furthermore, Istro-Romanian also shows instances of auxiliary-licensed verbal ellipsis (=VP-ellipsis), a phenomenon severely restricted in the Romance languages (see Nicolae 2019a: ch. IV for an overview). By using a standard minimalist generative grammar framework (see Section 1.3 below) and by working with the existing written corpora of Istro-Romanian ${ }^{3}$, we aim to demonstrate that the paradoxical properties briefly mentioned above (as well as many others, discussed throughout the paper) are best understood under the premises that Istro-Romanian auxiliaries are not clitics (see also Geană 2017). Therefore, in contrast to the auxiliaries of Daco-Romanian, Istro-Romanian auxiliaries are less grammaticalized (closer to full words on the Hopper and Traugott's (2003) 'grammaticalization cline'), and this morphophonological property has syntactic relevance. The non-clitic nature of Istro-Romanian auxiliaries will be shown to result from the combined effect of the conservative nature of this idiom (=retention of an archaic feature from an unattested stage of (proto-)Romanian) and language contact with Croatian ${ }^{4}$.

\subsection{Conceptual Tools}

In what follows, we adopt the current generative view on clause structure (1), according to which finite clauses are made up of three domains: the CP-domain, the IP(/TP)domain and the $v \mathrm{P}$-domain(/v-VoiceP)-domain. Research in this area has revealed that, cross-linguistically, any of the three domains can be targeted by V-raising/movement. It is well-known that these domains themselves are made up of a relevant number of projections-cf., for example, Rizzi's (1997) split-CP analysis or Cinque's (1999) cartographic approach; finer-grained structural details will be provided when necessary.

1 .

$$
\begin{aligned}
& \text { CP } \\
& \text { (continental) Germanic V2 } \\
& \text { old Romance V2 }
\end{aligned}
$$

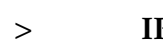

$\begin{array}{lll}\text { IP } & >\mathbf{P} \\ \text { modern Romance } & & \text { English }\end{array}$

It is also necessary to introduce some minimal background on the phenomena relevant for our argumentation.

Consider first auxiliary-licensed VP-ellipsis; the main properties of this phenomenon ${ }^{5}$ which occurs rather rarely cross-linguistically (it productively occurs in English) - are the following:

- $\quad$ it is a type of elliptical construction which is dependent on the existence of a licenser (a TAM auxiliary or a modal auxiliary);

- $\quad$ it is insensitive to clause type (main/embedded clause) and other conditions (e.g., in contrast to ellipses such as gapping, it is not parasitic on coordination);

- there are two conditions which need to be met for the licensing of this type of ellipsis (see Thoms 2010; Authier 2012, i.a.):

(i) lower verb movement of the lexical verb (movement below I);

(ii) non-clitic auxiliary verbs.

Secondly, a minimal background on verb morphosyntax in (Daco-)Romanian is also necessary; this provides a starting point for understanding the Istro-Romanian data. Up to the present point, research on old and modern (Daco-)Romanian has established the following:

- $\quad$ modern Romanian auxiliaries are clitics (Avram 1999); the same characteristic carries over to old Romanian too (Nicolae 2019b); 
- $\quad$ modern Romanian synthetic finite verbs are characterized by V-to-I movement (Dobrovie-Sorin 1994; Cornilescu 2000; Ledgeway 2015, i.a.);

$\bigcirc \quad$ in a framework that assumes a finer-grained cartographic structure of the IP in the tradition of Cinque (1999) (distinguishing a Mood field, a Tense field, and an Aspect field), synthetic finite verbs raise to the top-most I-field, Mood (Nicolae 2015; Schifano 2018);

$\bigcirc \quad$ in periphrastic constructions, both the auxiliary/auxiliaries and the lexical verb reside in the IP-domain (Alboiu and Motapanyane 2000; Nicolae 2015);

- $\quad$-to-C movement is restricted to imperatives, conditional imprecations, and gerunds in modern Romanian—and it always takes the shape of Rivero's $(1992,1994)$ Balkan 'Long Head Movement' (=LHM) rule, by which it is the lexical verb, not the auxiliary that moves to C;

- although statistically V-to-I movement is the dominant option (Nicolae 2015), Vto-C movement is more widespread in old Romanian (also occurring in finite nonimperative clauses), and (English-type) low(er) verb movement (on the surface manifested as scrambling and interpolation) is also found in old Romanian finite clauses (Nicolae 2019b);

- pronominal clitics are I-oriented in both old and modern Romanian (cf. Săvescu Ciucivara 2011; Hill and Alboiu 2016, i.a. $)^{6}$, and occupy dedicated projections at the edge of the IP-domain; in correlation with other syntactic diagnostics, the proclisis/enclisis alternation is relevant for assessing the level of verb movement (V-to-I/V-to-C).

Some terminological clarifications are also necessary.

- Interpolation represents the separation of the clitic pronoun from the finite verb by (an) intervening $\mathrm{XP}(\mathrm{s})$, while scrambling refers to the separation of the auxiliary verb from the lexical verb by (an) intervening $\mathrm{XP}(\mathrm{s})$. It has been shown that in the Romance languages multiple processes may lie behind the derivation of interpolation and scrambling; thus, while on the surface, each of these phenomena, in its own right, may appear to be a unified phenomenon, from a structural point of view, they are based on different processes (see also Poole 2007, p. 188, n. 1, who makes similar comments in the analysis of old Spanish). Hence, in what follows, we use the terms interpolation and scrambling to refer to the word order patterns described above; their structural analysis is assessed on the basis of syntactic diagnostics for each of the varieties examined here (Istro-Romanian, old Romanian, and Croatian).

- We use the label 'Long Head Movement' (LHM) (Rivero 1992, 1994) conventionally, to describe an empirical phenomenon specific (but not limited) to the Balkan languages: the displacement of a non-finite lexical verb across the auxiliary. Technical details on the derivation of LHM structures will be provided below.

In what follows, we set out to bring evidence for the main claim of the paper, namely that Istro-Romanian auxiliaries are not clitics. Viewed from a diachronic, Latin-to-Romance perspective, this property translates as the preservation of a more archaic status of IstroRomanian auxiliaries: while these verbs become functional elements showing the typical phenomena of auxiliation-(morpho)phonological reduction (in comparison to their etyma), loss of thematic structure, loss of morphosyntactic features (see, i.a., Roberts and Roussou 2003, ch. 3; Ledgeway 2016, p. 768) -from the perspective of Hopper and Traugott's (2003) grammaticalization cline, their status is that of full words (neither clitics, nor affixes). We argue that contact with Croatian acts as a catalyst of structural convergence engendering the retention of an archaic feature. As will be seen, the hypothesis that this is an archaic feature is supported by old Romanian data, as early old Romanian shows a few clear instances of auxiliary-licensed VP-ellipsis and related phenomena (interpolation and scrambling). 


\section{Three Phenomena Showing the Non-Clitic Nature of Istro-Romanian Auxiliaries}

\subsection{Auxiliary-Licensed VP-Ellipis}

The availability of VP-ellipsis in Istro-Romanian is a phenomenon which has not been discussed in the literature (Zegrean 2012, p. 122 briefly mentions it). From a comparative Romance perspective, this feature of Istro-Romanian is unexpected: in contrast to the other Romance languages, Istro-Romanian auxiliary-licensed VP-ellipsis brings this idiom closer to languages such as English. The following data, extracted from the corpora ${ }^{7}$, show that the phenomenon is frequent. In what follows, we present the distribution of auxiliary-licensed VP-ellipsis in Istro-Romanian.

(i) The auxiliary licenses ellipsis in main clauses. Ellipsis is found with the perfect auxiliary $(2 \mathrm{a}-\mathrm{e})$, the future auxiliary $(2 \mathrm{f})$, and the conditional auxiliary $(2 \mathrm{~g}, \mathrm{~h})$. The symbol $\sqrt{ }$ marks the ellipsis site; in situations in which the antecedent is not immediately obvious from the immediate context, it is represented in brackets $<>$.

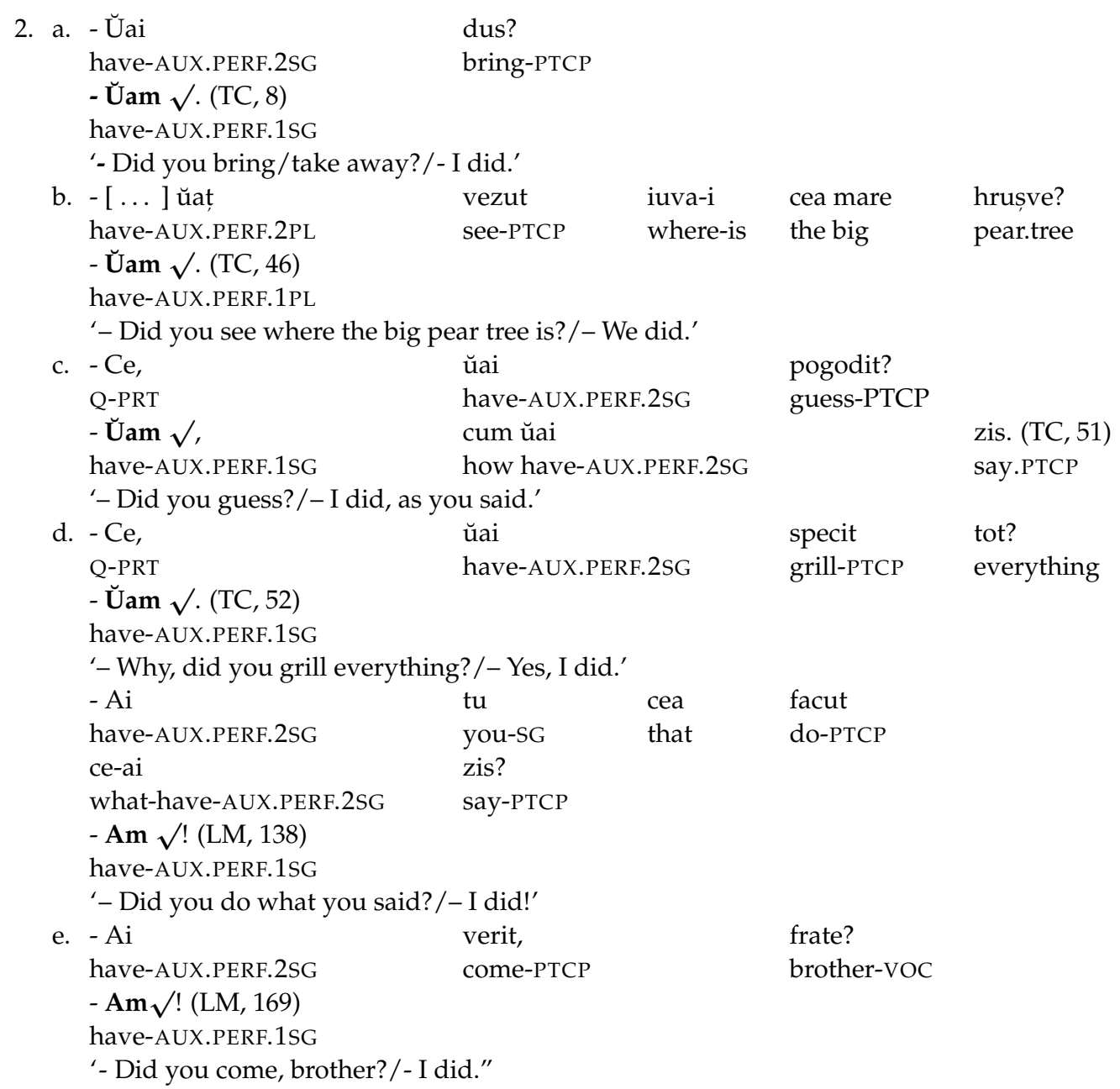


f. - Grofu av

\begin{tabular}{|c|c|c|}
\hline count & have-AUX.PERF.3SG & order-РТСР th \\
\hline ănsura c-alui $(\ldots)$ & fil'e, & e io \\
\hline marry with-his & daughter & and I \\
\hline $\begin{array}{l}\text { poc. } \\
\text { can-IND.PRES.1SG } \\
\text { oucearule? } \\
\text { shepherd-VOC }\end{array}$ & $\begin{array}{l}\text { Ver } \sqrt{ } \\
\text { will-AUX.F }\end{array}$ & \\
\hline vo & voi $\sqrt{ }$, & io! (LM, 123) \\
\hline & will-AUX.FUT.1SG & I \\
\hline
\end{tabular}

'- The count ordered that I have to marry his daughter, but I am married; I can't. Will you, shepherd?/- I will.'

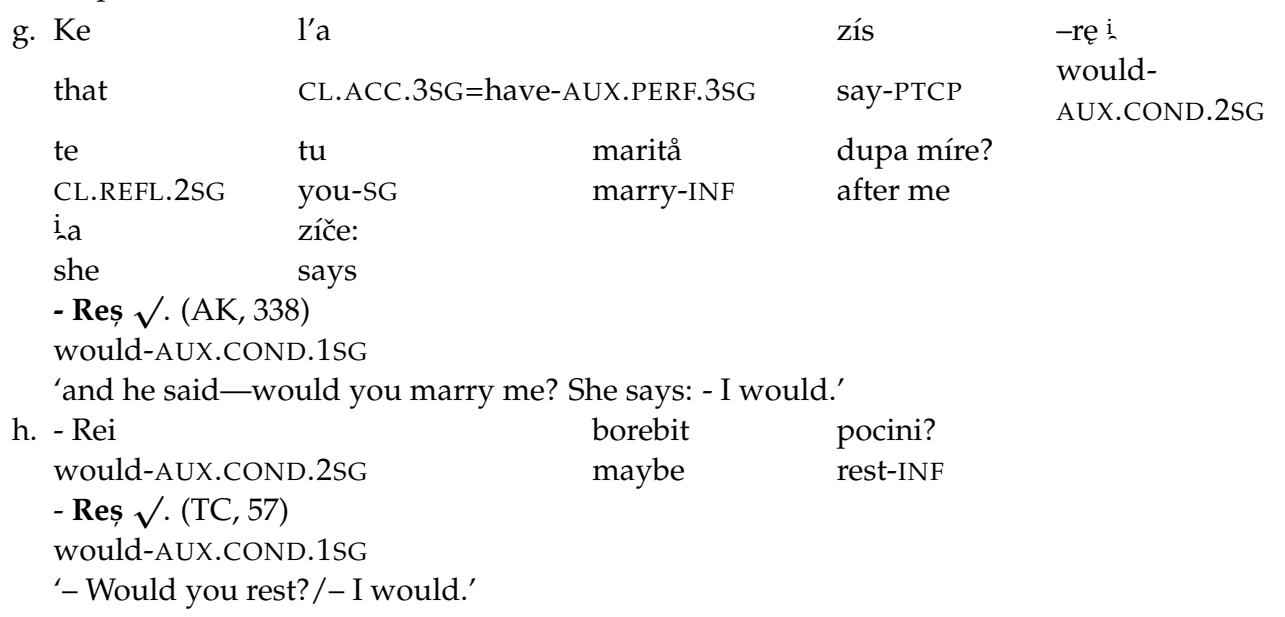

(ii) The auxiliary licenses ellipsis in embedded clauses. In our corpus survey, we have identified the perfect auxiliary (3a) and the future auxiliary (3b) in these contexts.

3. a. - Cuheit-ŭai?

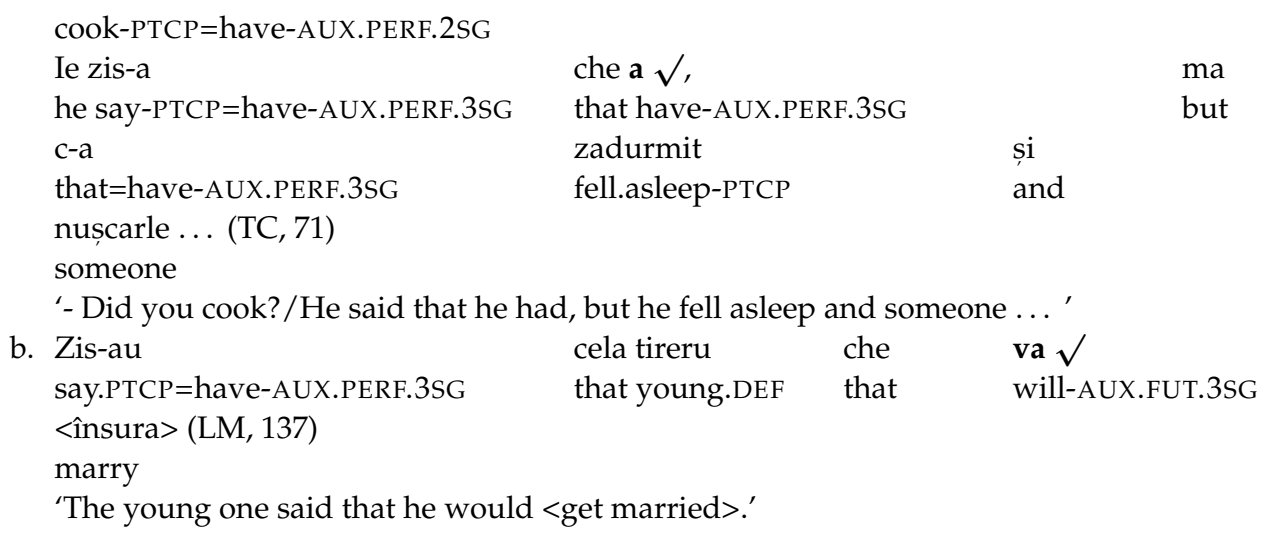

(iii) Auxiliary-licensed VP-ellipsis is also available in negative clauses: 


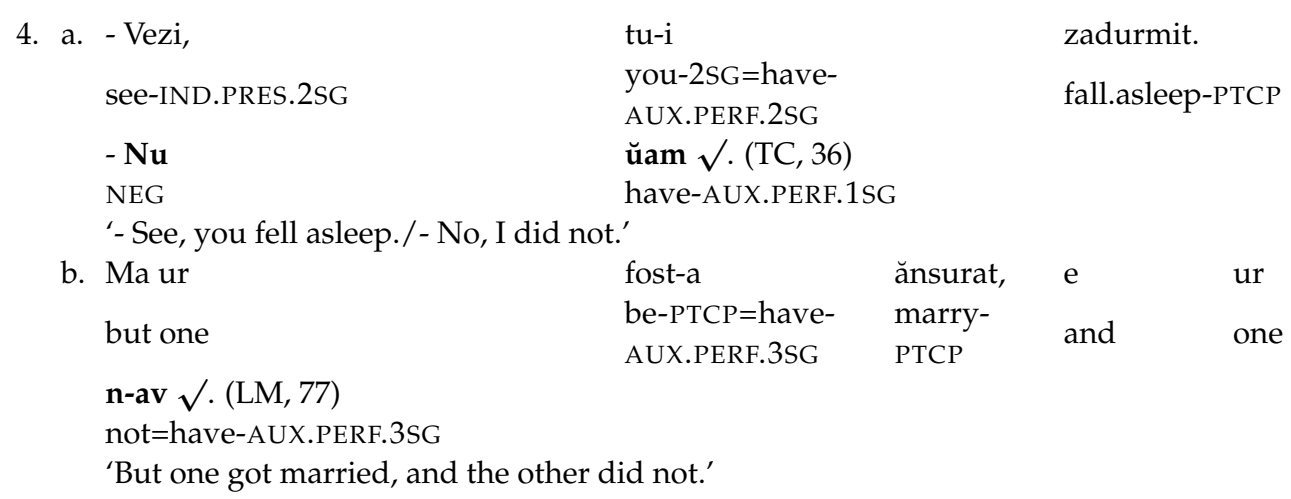

(iv) In other cases (5), the auxiliary licenser is also followed by remnants:

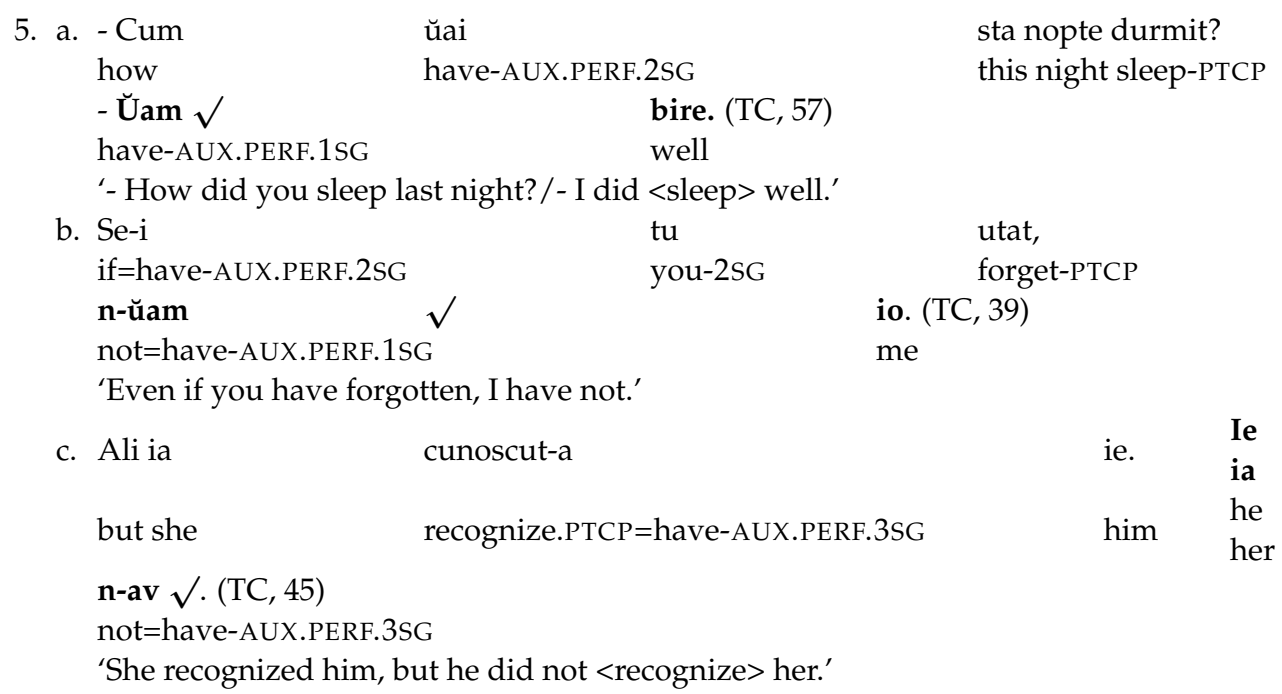

The features in (i)-(iv) show that the auxiliary-licensed VP-ellipsis in Istro-Romanian has the same properties as its English counterpart (see Section 1.3 above).

\subsection{Discontiguous Verbal Clusters as Evidence for Low Verb Movement}

In previous work, we have brought evidence in favour of the hypothesis that, in contrast to modern Daco-Romanian, Istro-Romanian shows numerous instances of low verb movement (Dragomirescu and Nicolae 2018). Low(er) verb movement is also found in old Romanian (Nicolae 2019b) (see also Section 3.2.1 below). The tools for diagnosing low(er) verb movement are the diagnostic adverbs for V-movement (Section 2.2.1) in Cinque's (1999) hierarchy (see Schifano 2018 for an update and revised hierarchy) and other patterns of discontiguity in the verbal cluster-scrambling for periphrastic structures and interpolation for synthetic structures (Section 2.2.2).

The existence of low(er) verb movement is directly relevant to our argumentation: it is a property which directly correlates with the availability of auxiliary-licensed VP-ellipsis, which, in its turn, acts in correlation with non-clitic auxiliaries.

\subsubsection{Scrambled and Interpolated Adverbs}

The most significant argument for low verb movement is the position of Cinque's diagnostic adverbs for V-movement. In particular, we observe that the lexical verb occurs to the right of the adverbs 'well', 'already', 'then' (6a-e), themselves preceded by the auxiliary; it is well known that these adverbs lexicalize various specifiers in Cinque's (1999) hierarchy: 'well' marks the boundary between the IP-domain and the vP-domain, 'already' and 'then' are T-oriented adverbs. Other (circumstantial) adverbs (6f-g) may also occur in between the auxiliary and the lexical verb. 


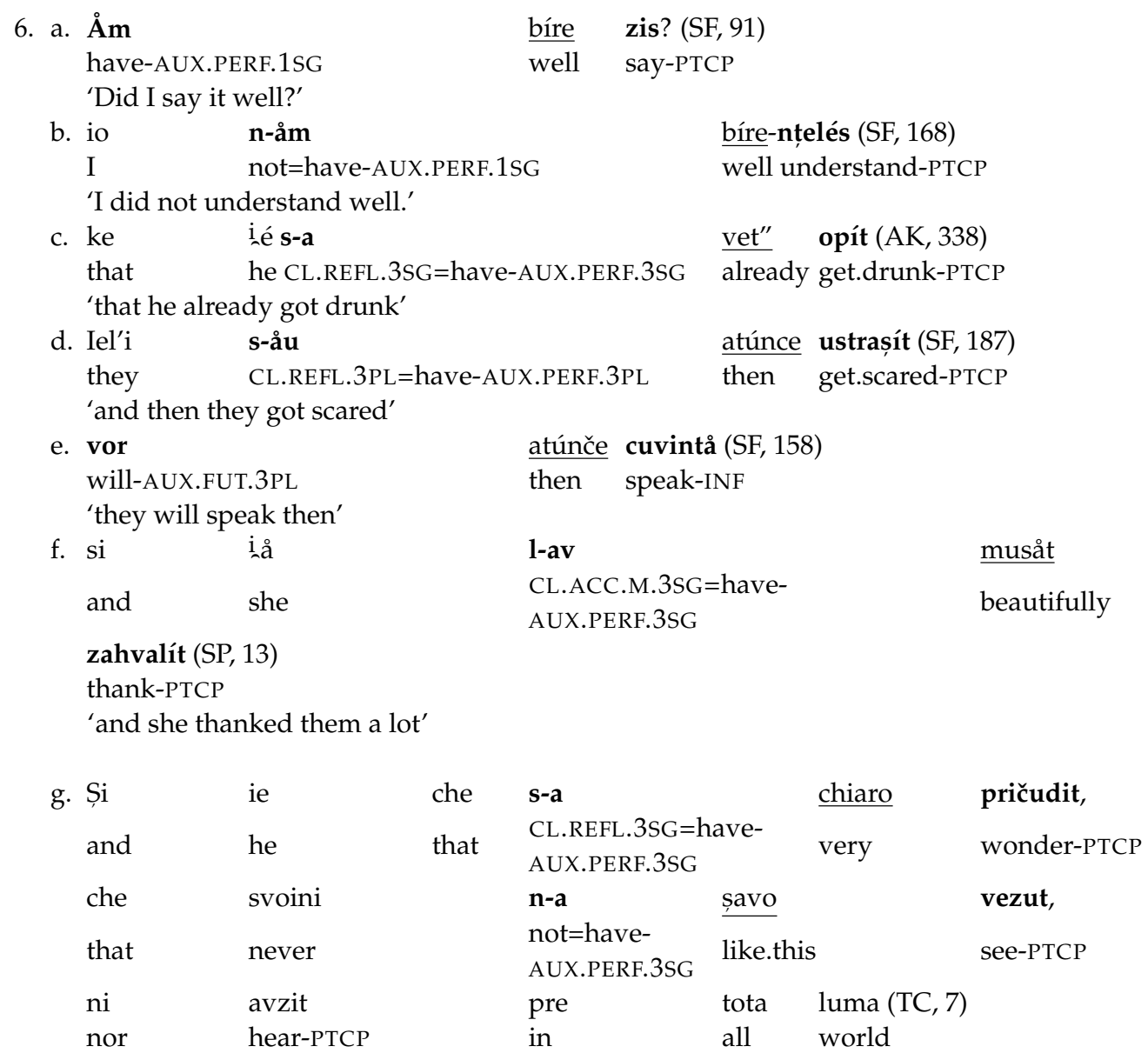

'And he was very astonished, because he had never seen something like this, anywhere in the world.'
h. io n-åm $\quad$ colę fos $(S F, 155)$
I not=have-AUX.PERF.1SG there be-PTCP
'I wasn't there.'

Moreover, in structures without auxiliaries, these adverbs occur in preverbal position; notice (7a) in particular, where the 'well'-adverbial is trapped between the subject and the synthetic lexical verb, clearly indicating a low position of the lexical verb on the spine ${ }^{8}$.

\begin{tabular}{|c|c|c|c|c|}
\hline 7. a. & ke & voi & bíre & știț (SF, 177) \\
\hline & $\begin{array}{l}\text { that } \\
\text { 'that you know well' }\end{array}$ & $\overline{\text { you}}-\mathrm{PL}$ & $\overline{\text { well }}$ & knOw-IND.PRES.2PL \\
\hline b. & $\begin{array}{l}\text { si } \\
\text { and }\end{array}$ & $\frac{\text { mușat }}{\text { beautifully }}$ & & $\begin{array}{l}\text { zehvales (TC, 11) } \\
\text { thank-IND.PRES.1SG }\end{array}$ \\
\hline
\end{tabular}

The position of the lexical verb with respect to adverbials is an indicator for a lower position of the lexical verb on the clausal spine ${ }^{9}$.

\subsubsection{Other Patterns of Scrambling}

The scrambling of several types of constituents in between the auxiliary and the lexical verb has a double significance: on the one hand, it is a supplementary argument for low verb movement; on the other hand, it shows that Istro-Romanian auxiliaries show a lower degree of grammaticalization being self-standing verbal elements, at least when compared to Daco-Romanian (Dragomirescu and Nicolae 2016, 2018). The constituents that can occur in between the auxiliary and the lexical verb are: the subject realized as a simple nominal phrase (8a) or as a complex one (8b), the prepositional object (8c), the temporal adverbial 
and the direct object (8d), the pronominal subject and the manner adverbial (8e), etc.

\begin{tabular}{|c|c|c|c|c|c|}
\hline a. & $\begin{array}{l}\text { Cănd a } \\
\text { when ha } \\
\text { 'when tl }\end{array}$ & $\begin{array}{l}\text { e-AUX.PERF.3SG } \\
\text { emperor found out' }\end{array}$ & $\frac{\underline{\text { cesaru }}}{\text { emperor- }}$ & & $\begin{array}{l}\text { dozneit }(\mathrm{TC}, 23) \\
\text { find.out-PTCP }\end{array}$ \\
\hline b. & $\begin{array}{l}\text { Cănd } \\
\text { when } \\
\text { cu } \\
\text { with } \\
\text { 'When thi }\end{array}$ & $\begin{array}{l}\text { au } \\
\text { have-AUX.PERF.3SG } \\
\text { merinda (TI, 146) } \\
\text { lunch } \\
\text { man's wife brought lun }\end{array}$ & $\frac{\text { mul'era }}{\text { wife }}$ & $\frac{\text { lu }}{\text { GEN }} \frac{\text { cesta }}{\text { this }}$ & $\begin{array}{ll}\frac{\text { úom }}{\text { man }} & \text { verit } \\
\text { come-РТCP }\end{array}$ \\
\hline c. & $\begin{array}{l}\text { Iel' } \\
\text { they.NOM } \\
\text { si } \\
\text { and } \\
\text { 'They thar }\end{array}$ & $\begin{array}{l}\text { a } \\
\text { s-a } \\
\text { CL.REFL.3PL=have.AU } \\
\text { sed her and greeted her. }\end{array}$ & $\begin{array}{l}\text { PERF.3PL } \\
\text { RF.3PL }\end{array}$ & $\begin{array}{l}\text { zehvalit } \\
\text { thank-PTCP } \\
\underline{\text { cu ie }} \\
\text { with her-ACC }\end{array}$ & $\begin{array}{l}\text { pozdravit }(\mathrm{TC}, 12) \\
\text { greet-PTCP }\end{array}$ \\
\hline d. & $\begin{array}{l}\text { și } \\
\text { and } \\
\text { vezut (TC, } \\
\text { see-PTCP } \\
\text { 'and I did }\end{array}$ & $\begin{array}{ll}\text { inche } & \text { n-ŭan } \\
\text { yet } & \text { not=h } \\
\text { 2) } & \text { AUX.P } \\
\text { ot see any human anyw }\end{array}$ & 1SG & $\frac{\text { nigdar }}{\text { nowhere }}$ & $\begin{array}{l}\underline{\text { ŭom }} \\
\text { human-ACC }\end{array}$ \\
\hline e. & $\begin{array}{l}\text { cum } \\
\text { as }\end{array}$ & $\begin{array}{l}\text { ŭam } \\
\text { have-AUX.PERF.1SG }\end{array}$ & $\frac{\text { io }}{\mathrm{I}-\mathrm{NC}}$ & & $\begin{array}{l}\text { bire zis }(\mathrm{TC}, 45) \\
\text { well say-РTCP }\end{array}$ \\
\hline
\end{tabular}

Scrambling is also found in old Romanian, alongside interpolation (see Dragomirescu 2013; Nicolae 2019b, ch. 3). As shown in Nicolae (2019b), there is no evidence for Aux-to-C movement in old Romanian; therefore, strings of the form Aux-(scrambled) XP(s) - V (in conjunction with other properties of old Romanian) constitute convincing evidence in favour of a lower position of the verb on the clausal spine. By contrast, as argued in previous work (Dragomirescu and Nicolae 2020) and as will also be shown below, Aux-to-C movement is available in Istro-Romanian; from this perspective, scrambling is compatible in Istro-Romanian with two structural analyses (being an instance of parametric ambiguity in the sense of Clark and Roberts 1993) — one in which the Aux resides in the IP and another with Aux-to-C movement-hence, it only represents partial evidence for low verb movement. However, due to the particular word order of the scrambled elements, there are examples such as (8e) which clearly favour an analysis in which the verb occupies a lower position on the clausal spine. In this example, the nominative subject io (' $\left.\mathrm{I}^{\prime}\right)$ precedes the vP-edge adverbial bine ('well'), which in its turn precedes the lexical verb; the most plausible analysis takes the subject to be in the canonical Spec,TP position and the adverbial in its base position, thus with the lexical verb occupying a lower position (presumably on the edge of the $v \mathrm{P}$-domain), irrespective of the position of the auxiliary.

To sum up, Istro-Romanian scrambling also provides indirect evidence for low verb movement.

\subsection{Aux-to-C and Other Word Order Patterns with Pronominal Clitics and Auxiliaries}

As extensively shown in Dragomirescu and Nicolae (2020), Istro-Romanian also shows instances of Aux-to- $\mathrm{C}$ movement, reflected by the Aux-Cl ordering. It is highly likely that Aux-to-C is, in part, an effect of language contact, as it is well known that Croatian displays Wackernagel cliticization (Čamdžić and Hudson 2007; Schütze 1994; Migdalski 2009). However, there are examples such as (9b) that show that Aux-to-C also occurs when the clause-initial position is occupied by another prosodically integrated constituent. 


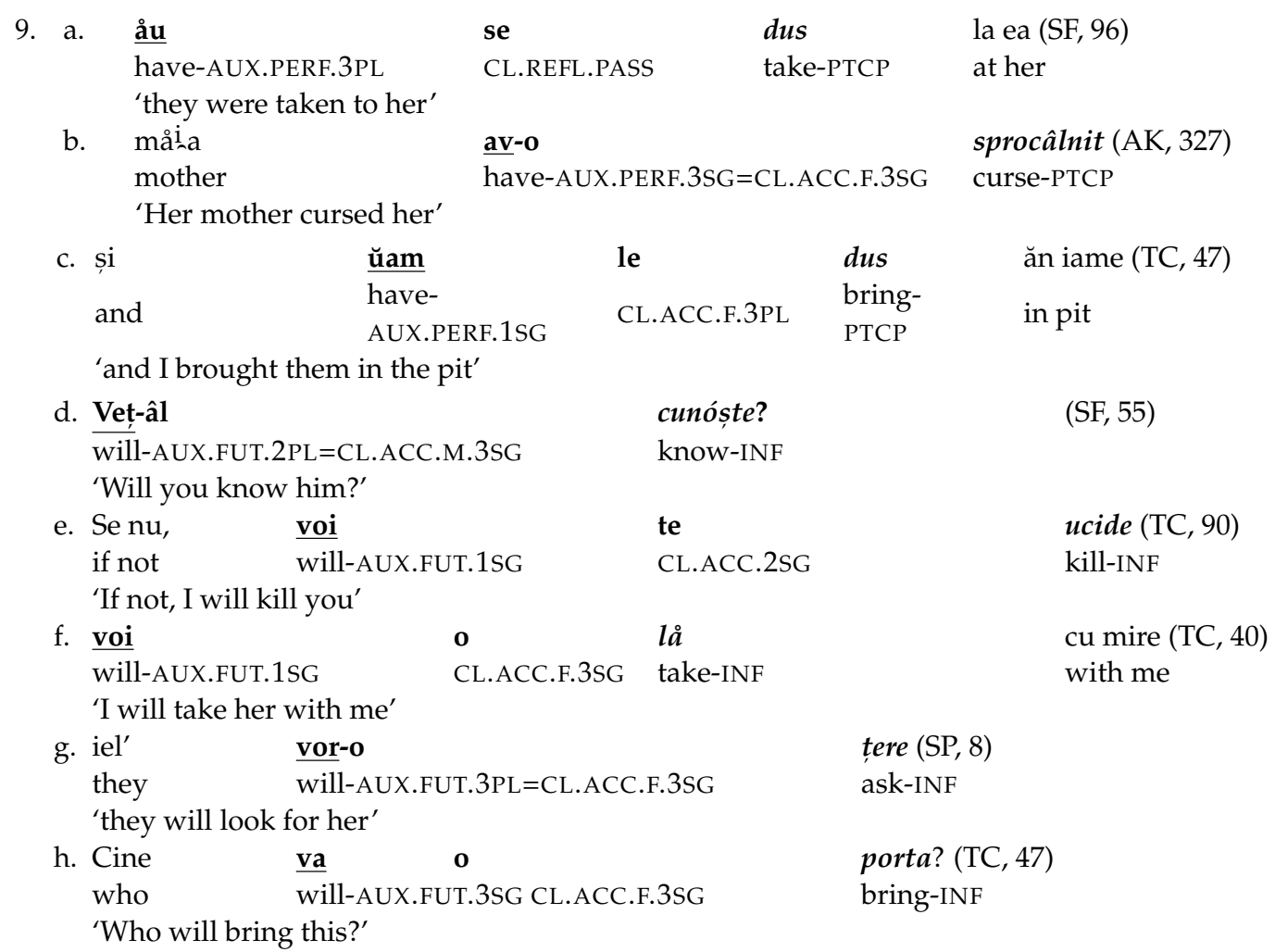

The fact that Aux-to-C in Istro-Romanian may be partially determined by Wackernagel's law (either imported from Croatian as an effect of language contact, or preserved in Istro-Romanian from a medieval Romance phase in the form of the Tobler-Mussafia law ${ }^{10}$, "ultimately a Romance-specific reanalysis of the Wackernagel Law", as characterized by Ledgeway 2012, p. 161) is in itself a supplementary piece of evidence in favour of the nonclitic nature of Istro-Romanian auxiliaries: auxiliaries are good candidates for occupying a clause-initial position; hence, they are not clitics.

Moreover, in clusters with pronominal clitics, auxiliaries, and lexical verbs, virtually every word order possibility is attested: besides Aux $-\mathrm{Cl}-\underline{\mathrm{V}}$ (9), we find Aux- $\mathrm{V}-\mathrm{Cl}$ (10a), Cl-Aux- $\mathrm{V}$ (10b); Cl-V-Aux (10c); $\mathrm{V}-\mathrm{Cl}$-Aux (10d); $\mathrm{V}-\mathrm{Aux}-\mathrm{Cl}$ (10e). This flexibility shows that Istro-Romanian patterns both with Daco-Romanian and the Balkan languages more generally - in displaying LHM patterns (Rivero 1994) such as (10d) and (10e)—and with the (older stages of the) Western Romance languages ${ }^{11}$ - through the availability of Auxto- $C$ movement (9), (10a). Thus, both the lexical verb and the auxiliary are equally good candidates for movement to $\mathrm{C}$. 


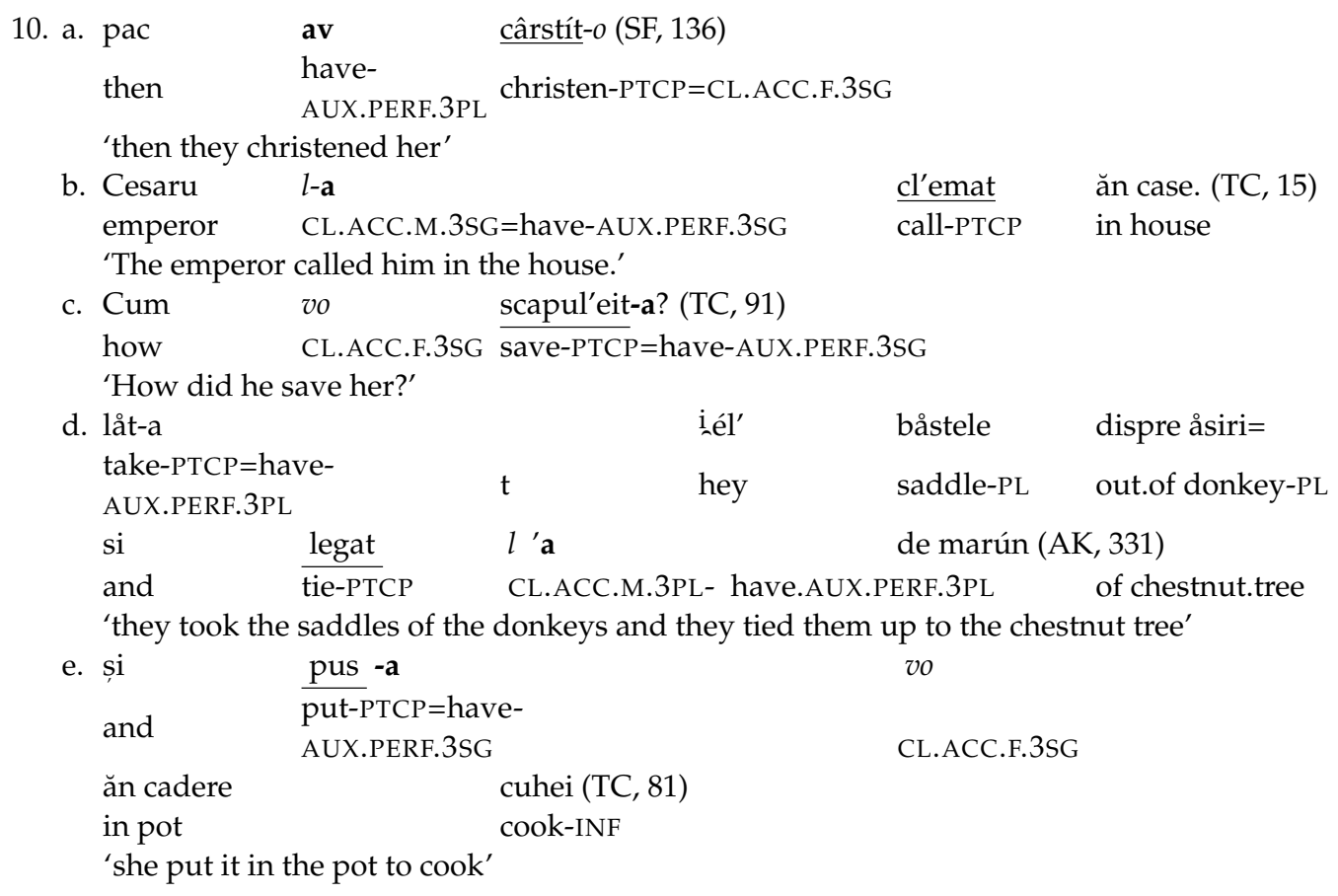

Relevance for the status of Istro-Romanian auxiliaries. We believe that this word order flexibility is highly relevant for the status of Istro-Romanian auxiliaries.

In previous work, Nicolae $(2015,2019 b)$ has argued that lexical verbs, not auxiliaries, may undergo movement to $C$ in old Romanian, and that this is determined by their morphophonological nature. To be more precise, it is shown that Rivero's (1994) LHM pattern is derived by Vicente's (2007) (cf. also Kayne 1991) V0-to-Spec analysis (an analysis also adopted by (Harizanov 2016) in the derivation of Bulgarian participle fronting). Old Romanian auxiliaries (which are clitics) remain in situ, while lexical verbs move to $C$; evidence that clitics themselves cannot move to $C$, while non-clitic elements may undergo movement to $\mathrm{C}$ comes from the incorporation of clitic adverbs (clitic adverbials incorporate into the structure of the lexical verb and move along with it, but cannot themselves move) and from the blocking effects of phrasal negation on V-to-C movement ${ }^{12}$. Turning now to Istro-Romanian, from the sets of examples in (9) and (10), it appears that both lexical verbs and auxiliaries may undergo movement to $\mathrm{C}$. Applying the same logic as for old Romanian, it follows that in Istro-Romanian auxiliaries too may be categorized as non-clitic elements, this ensuring their eligibility for movement to $\mathrm{C}^{13},{ }^{14}$.

As a side note, it is important to specify that, up to the present movement, we have not been able to identify a clear trigger of verb movement to $C$ (be it an auxiliary or the lexical verb) in Istro-Romanian. On the Croatian pattern, Wackernagel requirements might be one of the causes, but this does not hold for all the situations where we find verb movement to C. This state of affairs strongly resembles old Romanian, where a clear trigger for V-to-C movement could not be identified either, a fact which lead to interpreting old Romanian V-to-C movement as an instance of old Romance "relaxed" V2 ${ }^{15}$, whereby movement to C is triggered by a formal feature in the C-domain, which does not have a clear functional correlation.

To sum up, Aux-to-C movement is relevant for assessing the status of Istro-Romanian auxiliaries: if we agree that, as in old Romanian, only non-clitic elements many undergo movement to $C$, then the fact that Istro-Romanian auxiliaries may undergo movement to $C$ indicates that they are not clitics.

\subsection{Summary: Non-Clitic Auxiliaries in Istro-Romanian}

In this section, we have reviewed the evidence in favour of analysing Istro-Romanian auxiliaries as full words (non-clitic elements); this consists in the following: 
- $\quad$ ability of auxiliaries to license VP-ellipsis;

- scrambling and interpolation, formally analysed as instances of low(er) verb movement on the clausal spine;

- Aux-to-C movement; Istro-Romanian auxiliaries may undergo movement to $C$ just as the lexical verb of Daco-Romanian and other Balkan languages that display LHM.

\section{Retention of an Archaic Feature vs. Contact: Old Romanian and Croatian}

In this section, we examine the phenomena discussed above with respect to old Romanian and Croatian, in order to formulate a proper analysis of the Istro-Romanian data. One of the important goals of this paper is to determine the weight played by heritage vs. language contact in the syntax of Istro-Romanian, and VP-ellipsis and the other word order phenomena discussed here offer the perfect setting to carry out this investigation.

\subsection{VP-Ellipsis}

\subsubsection{Old Romanian}

In old Romanian, VP-ellipsis is very rarely attested (the five examples in (11)—see Nicolae 2019b, p. 85; Zamfir 2007, pp. 163, 320; Carabulea 2007, p. 45). In four of these examples, (11a), (11b), (11d), (11e), the ellipsis is co-licenced: the auxiliary is accompanied by functional material with which it makes up a cluster. Co-licensing is a form of phonological enhancement that bypasses the morphophonological licensing problem of auxiliaries: it indicates that old Romanian auxiliaries are transitioning from a full word status to a clitic status.

\begin{tabular}{|c|c|c|c|c|c|}
\hline \multirow[t]{6}{*}{ a. } & $\begin{array}{l}\text { de să } \\
\text { if CL.REFL.PASS }\end{array}$ & $\begin{array}{l}\text { va } \\
\text { will-AUX.FUT.3SG }\end{array}$ & \multicolumn{2}{|c|}{ cunoaste carii } & \\
\hline & & & \multirow{4}{*}{$\begin{array}{l}\text { rănit } \\
\text { hurt-PTCP }\end{array}$} & \multirow{5}{*}{$\begin{array}{l}\text { si } \\
\text { and }\end{array}$} & \\
\hline & CL.ACC.3SG.M=hav & AUX.PERF.3PL & & & \\
\hline & carii nu & 1-au $\sqrt{ }($ Prav.1646: 168) & & & \\
\hline & who NEG & CL.ACC.3SG.M=have-AUX.PERF.SG & & & \\
\hline & 'if it will be known & ho hurt him and who did not' & & & \\
\hline \multirow[t]{5}{*}{ b. } & cine & l-au & rănit & & si \\
\hline & who & CL.ACC.M.3SG=have-AUX.PERF.3SG & hurt-PTCP & & and \\
\hline & cine & l-au & $\sqrt{ }$ & & \\
\hline & who & \multicolumn{3}{|c|}{ CL.ACC.M.3SG=have-AUX.PERF.3SG } & \\
\hline & 'who hurt him and & ho did not'(Prav.1646:168) & & & \\
\hline \multirow[t]{7}{*}{ c. } & De & voiu & aceasta & plată & \\
\hline & if & will-AUX.FUT.1SG & by will & payment & \\
\hline & $\mathrm{am}$; & iară să & voiu $\sqrt{ }$, & fără & de voe, \\
\hline & $\begin{array}{l}\text { have- } \\
\text { IND.PRES.1SG }\end{array}$ & but if & will-AUX.FUT.1SG & without & by will \\
\hline & vistiernicie & mi-e & \multicolumn{2}{|l|}{ data. } & \\
\hline & treasury & CL.DAT.1SG=be-IND.PRES.3SG & \multicolumn{2}{|l|}{ give-PTCP } & \multirow{6}{*}{$\begin{array}{l}\text { sau } \\
\text { or }\end{array}$} \\
\hline & 'If I do this willingl & I will be paid; but if I (do it) unwillingly, I will be give & n the treasury (departmer & t).' (NT.1648:231r) & \\
\hline \multirow[t]{5}{*}{ d. } & de-l & va & & & \\
\hline & if $=C L \cdot A C C \cdot M \cdot 3 S G$ & will-AUX.FUT.3SG be-IRR ${ }^{16}$ & \multirow{4}{*}{$\begin{array}{l}\text { mutat } \\
\text { move-PTCP } \\
\text { fi } \sqrt{ } \\
\text { be-IRR }\end{array}$} & & \\
\hline & de & nu-l & & & \\
\hline & if & $\overline{\mathrm{not}}=\mathrm{CL} \cdot \mathrm{ACC} \cdot \mathrm{M} \cdot 3 \mathrm{SG}$ & & & \\
\hline & 'whether he has mo & ed it (=the border) or has not' (Prav.1646:78) & & & \\
\hline \multirow[t]{4}{*}{ e. } & de & va & gresit & \multirow{4}{*}{$\begin{array}{l}\text { înșelăciune } \\
\text { fraud }\end{array}$} & \\
\hline & if & will-AUX.FUT.3SG & \multirow{2}{*}{$\begin{array}{l}\mathrm{cu} \\
\text { with } \\
\text { fi } \sqrt{ }\end{array}$} & & \\
\hline & sau & va & & & \\
\hline & & will-AUX.FUT.3SG be-IRR & & & \\
\hline
\end{tabular}

As will be shown below (see Section 3.2.1), the other condition on VP-ellipsis licensing is met: old Romanian shows evidence for low(er) verb movement on the clausal spine.

\subsubsection{Croatian}

Auxiliary-licensed VP-ellipsis is also attested in BCS (12) (Stjepanović 1998), as shown in (12). Arguing that clitics are located in different projections in syntax, Stjepanović (1998) shows that the size of the ellipsis site is variable: in (12b), ellipsis targets both the dative and the accusative clitic (along with the lexical verb), while in (12c), in the same configuration 
under VP-ellipsis, the accusative clitic is elided along with the lexical verb and the dative clitic is preserved. However, (12d) shows that ellipsis cannot operate discontinuously by deleting, along with lexical verb, the dative clitic and preserving the accusative clitic.

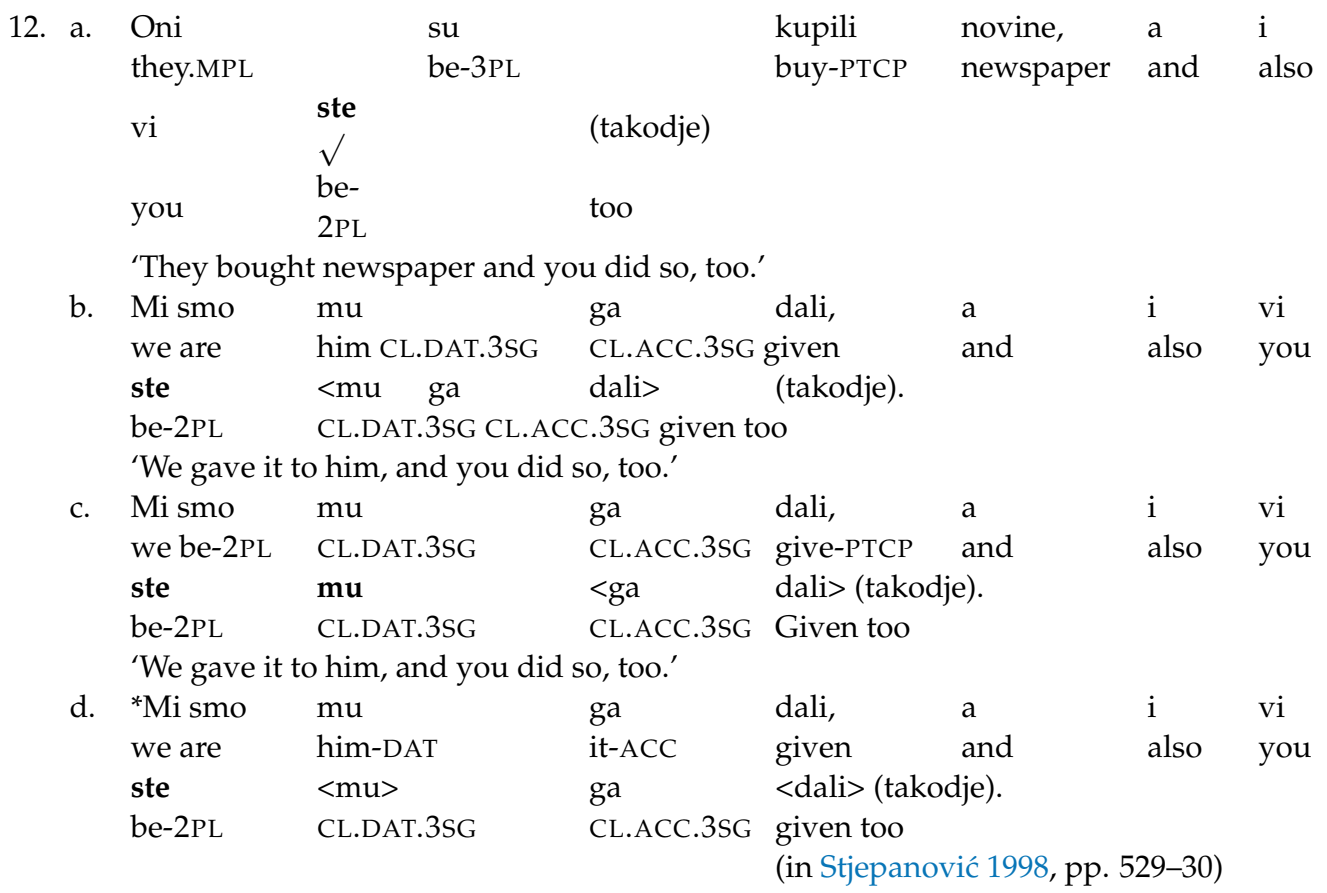

While it is not entirely clear whether the same formal analysis can be given to this type of ellipsis in Croatian and Istro-Romanian (and old Romanian, see Section 3.1.1 above), what is relevant is the existence of surface string identity in the two idioms in contact: just as in Croatian, in Istro-Romanian, an auxiliary can also license the ellipsis of the lexical verb with which it is associated.

\subsection{Discontiguous Verbal Clusters and Their Relevance}

\subsubsection{Old Romanian Interpolation and Scrambling: Low Verb Movement}

Low(er) verb movement on the clausal spine is also found in old Romanian. The different patterns of scrambling and interpolation, with and without Cinque's diagnostic adverbs for $\mathrm{V}$-movement, represent empirical evidence in favour of this analysis. For the limited purposes of this paper, we illustrate the phenomenon with a few relevant examples, but the reader is referred to Nicolae (2019b: ch. 3) for an extensive discussion which brings to the fore more phenomena and data, more than those presented here.

In synthetic structures, adverbs (13) are among the constituents interpolated; note that pururea ('always') (13a) and iară ('again') (13b) are part of the set of Cinquean diagnostic adverbs for V-movement (merging in the lower pre-VP area and lexicalizing an Asp perfect specifier and, respectively, an Asprepetitive specifier). (Floating) quantifier subjects may also be interpolated $(13 \mathrm{c})$.

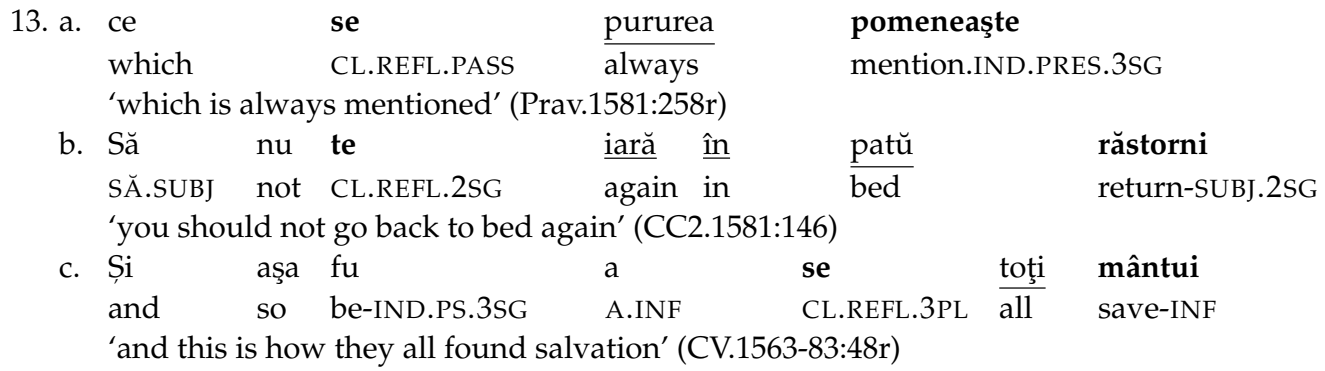


In analytic structures, the interposition of adverbials in between the auxiliary and the lexical verb is well represented. Thus, the following V-movement diagnostic adverbials are found: low adverbs such as bine ('well') (14), high adverbs such as amu ('now') (lexicalizing a T-related specifier) (15), and adverbial expressions such as acumuși, de sârg ('quicky') (16), which are ambiguous between an Asp-event reading and Asp-process reading, occupying different positions in Cinque's hierarchy (the high adverb space and the low adverb space, respectively). (Floating) quantifier subjects may also break the auxiliary-lexical verb cluster (17).

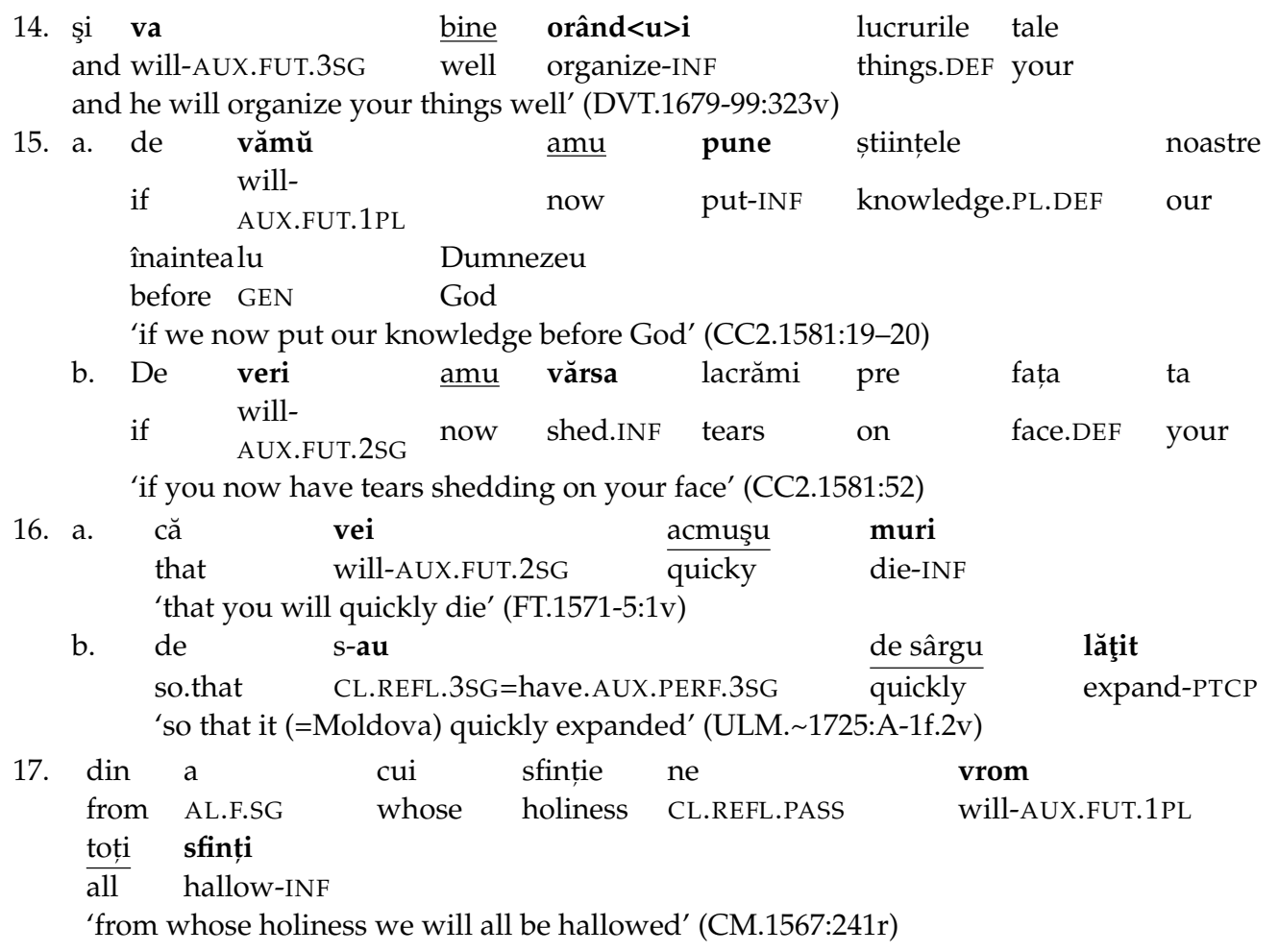

Multiple interpolated and scrambled constituents are possible:

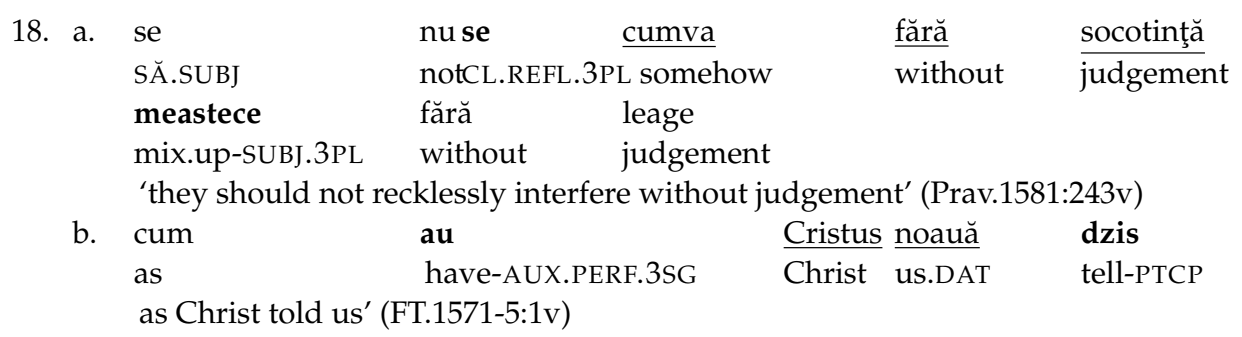

Nicolae (2019b: ch. 3) documents the entire range of interpolated and scrambled constituents; for the purposes of the present argument, the interpolation and scrambling of adverbials and of quantifiers represent good empirical evidence for the existence of the low(er) verb movement option in the grammar of old Romanian.

Furthermore, the statistical examination of interpolation and scrambling (see Nicolae 2019b, ch. 3) has shown that, in old Romanian, these phenomena preponderantly occur in embedded clauses. From a diachronic comparative Romance perspective, this distribution confirms the formal analysis based on low verb movement: it is expected for low verb movement to mostly occur in embedded clauses where V-to-C movement (i.e., V2) is generally blocked by the lexicalization of complementizers or wh-elements.

\subsubsection{Croatian Interpolation and Scrambling, and Their Relevance}

Defined as above (Section 1.3) (i.e., the separation of the clitic pronoun/auxiliary verb from the (finite) lexical verb), interpolation and scrambling are also found in BCS. Thus, in 
(19a-b), we see the adverbial 'always' separating the clitic pronoun from the synthetic verb, while in $(19 c-d)$, we see temporal and manner adverbs intervening between the auxiliary and the lexical verb.

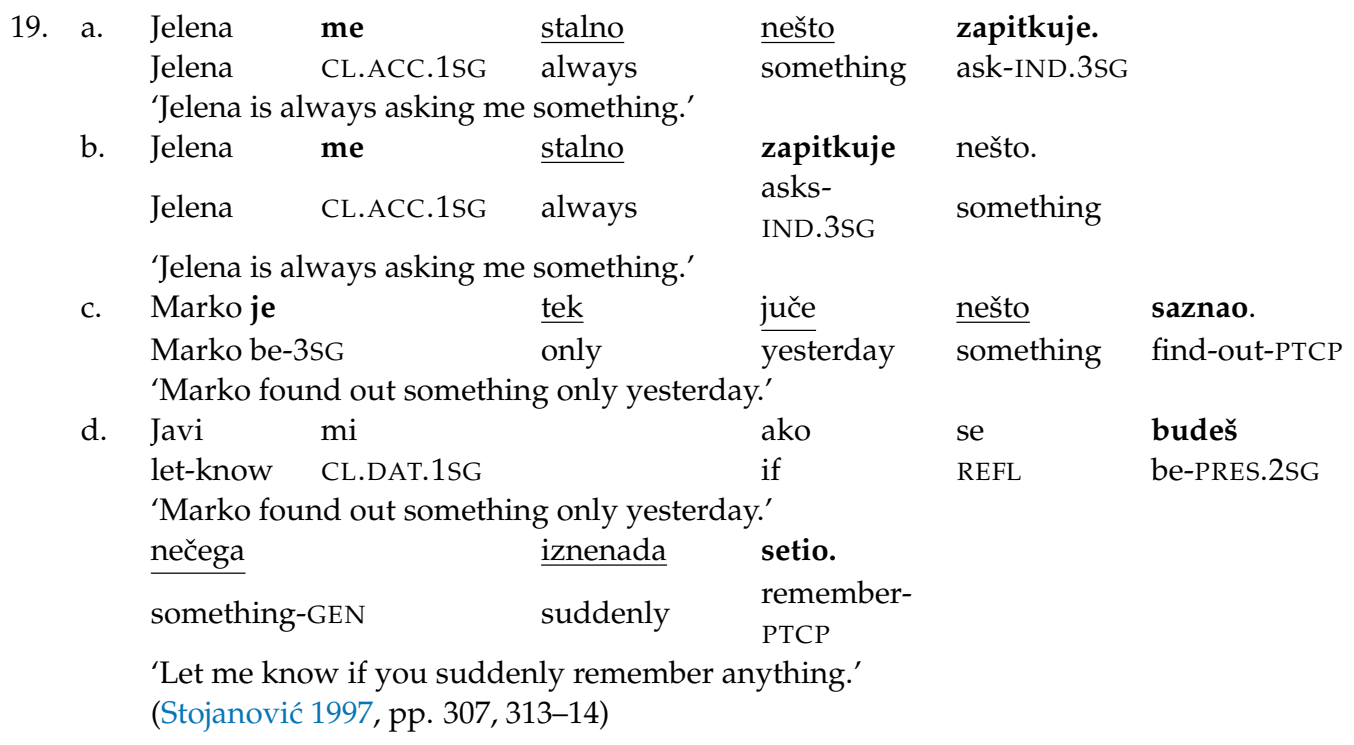

Note that more than one constituent can be interpolated (19a) or scrambled ((19c), (20)). Interpolation and scrambling occur both in main clauses (20a-b) and in embedded clauses (20c).

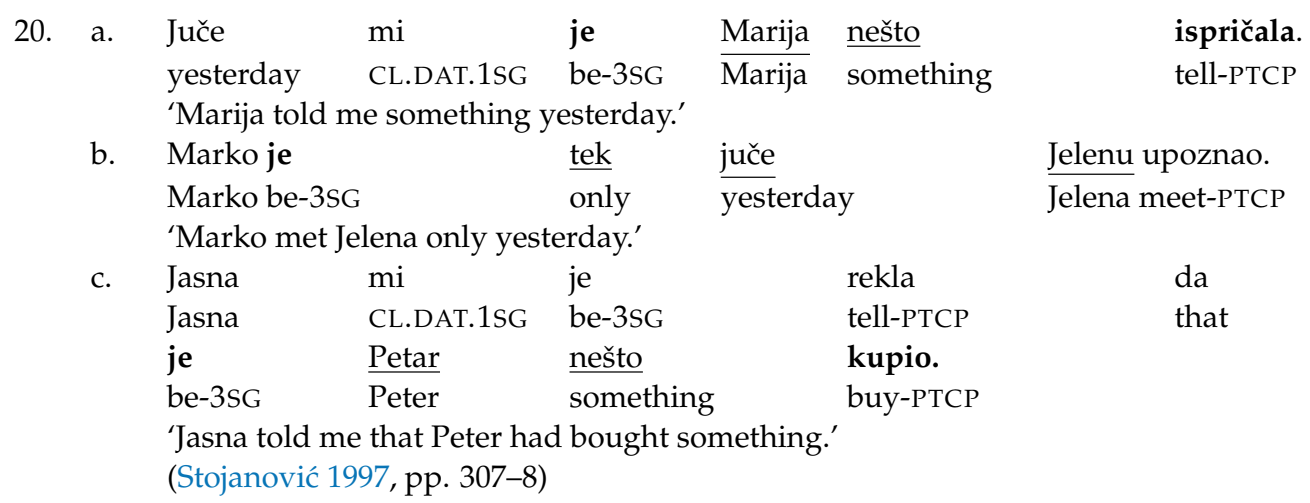

While it is clear that, on the surface, the phenomena in (18) to (20) are very similar to their Istro-Romanian and old Romanian counterparts, it is hard to determine whether these data can be analysed relying on the same rich clausal structure as that employed for Istro-Romanian and old Romanian, two Romance varieties. Given the C-orientation (and Wackernagel nature) of Croatian pronominal clitics (Mišeska Tomić 1996; Rivero 1997; Migdalski 2009), a formal analysis of interpolation based on low(er) verb movement is uncertain-at most speculative. On the other hand, Stojanović (1997, p. 310) observes that BCS main (i.e., lexical) verbs in periphrastic tenses do not raise out of the VP; thus, low(er) verb movement can be invoked, at least in the analysis of scrambling.

What is important for the purposes of the present analysis is the existence of these surface string identities in Croatian, Istro-Romanian, and old Romanian: this supports the idea that convergence obtains, even though it is limited to surface phenomena, not to deep structural properties.

\section{Analysis and Conclusions}

Putting aside the issue of what the correct formal analysis of the Croatian data is, what we unequivocally observe is the existence of surface string-identity: identical word order phenomena are found in old Romanian, Istro-Romanian (which shares the same ancestry as 
old Romanian), and Croatian/BCS (the contact language). From this perspective, language contact with Croatian appears to have acted as a catalyst: several word order patterns of the contact language overlap with similar patterns of the target language, even though they might not have the same syntactic structure. This overlap generates convergence (cf. Hickey 2010), ensuring the preservation of several archaic properties: in the particular case of auxiliaries, they retain the full word status, i.e., they do not move further up on Hopper and Traugott's (2003) grammaticalization cline. The representation below (Figure 1) summarizes the relation between Istro-Romanian, old Romanian, and Croatian:

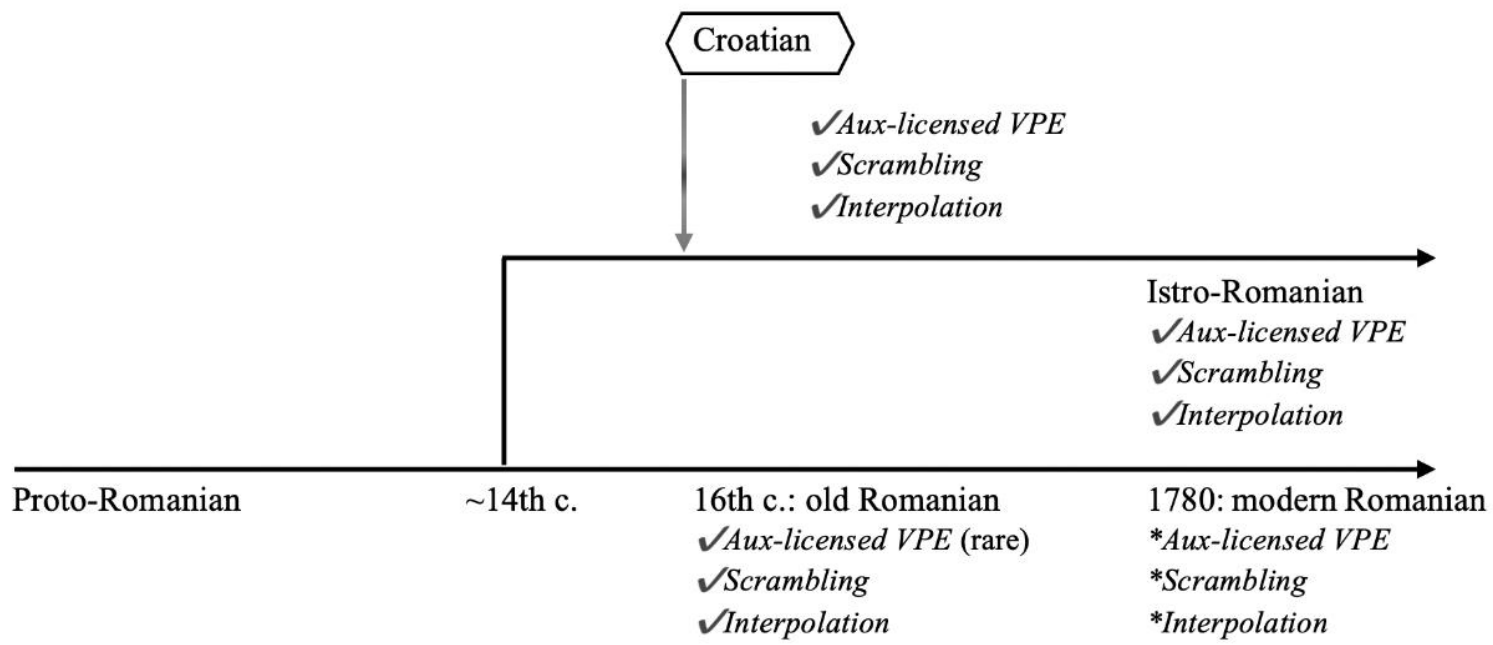

Figure 1. The relation between Istro-Romanian, old Romanian, and Croatian.

The existence of auxiliary-licensed VPE along with low verb movement represents convincing evidence for the non-clitic nature of auxiliaries. We believe that this is not a trivial property, limited to (morpho)phonological component. Since it occurs along with correlation with other properties, the non-clitic nature of auxiliaries is a feature that genuinely reflects some central properties of Istro-Romanian syntax. Secondly, it explains the massive variation found in the Istro-Romanian verbal nexus: being categorised as non-clitic elements, auxiliaries show the same displacement properties like full lexical verbs. Thus, along with the double setting of pronominal clitics, I-oriented (the Romance parameter setting) and C-oriented/Wackernagel (a setting resulting from contact with Croatian) (see Dragomirescu and Nicolae 2018, 2020), the word order freedom of auxiliary verbs, lexical verbs, and pronominal clitics described in Section 2.3 above derives from the fact that auxiliaries are equally good candidates for movement to C; Rivero's LHM rule may therefore affect auxiliaries too.

Our findings are consonant with recent scholarship on the effects of language contact in syntax. In the analysis of the Judeo-Spanish spoken in Bulgaria, besides confirming the fact that in language contact settings structures and elements belonging to narrow syntax are stable, while interface phenomena are vulnerable, Fischer (forthcoming) ${ }^{17}$ also shows that equivalence relations are important: "in order for these structures to be retained or innovated equivalence relations between languages in contact are relevant". The non-clitic auxiliaries of Istro-Romanian are a perfect illustration of this idea: a morphophonological property which has syntactic effects is retained as it instantiates an equivalence relation between the two languages - particularly, features associated with non-clitic auxiliaries are found both in Croatian and Istro-Romanian.

Author Contributions: Conceptualization, A.D. and A.N.; methodology, A.D. and A.N.; formal analysis, A.D. and A.N.; investigation, A.D. and A.N.; writing-original draft preparation, A.D. and A.N.; writing-review and editing, A.D. and A.N. All authors have read and agreed to the published version of the manuscript. 
Funding: This research was funded by two grants of the Romanian Ministry of Education and Research, CNCS-UEFISCDI, project number PN-III-P1-1.1-TE-2019-0832, within PNCDI III (for Adina Dragomirescu) and project number PN-III-P4-ID-PCE-2020-1097, within PNCDI III (for both authors).

Institutional Review Board Statement: Not applicable.

Informed Consent Statement: Not applicable.

Conflicts of Interest: The authors declare no conflict of interest.

\section{Corpus}

Istro-Romanian

AK = Kovačec, August. 1998. Istrorumunjsko-hrvatski rječnik (s gramatikom i tekstovima). Pula: Mediteran.

LM = Morariu, Leca. 1928. Lu Frați Noștri. Libru lu Rumeri din Istrie. Suceava: Editura Revistei "Făt-Frumos".

SF = Sârbu, Richard, and Vasile Frățilă. 1998. Dialectul istroromân. Texte și glosar. Timișoara: Editura Amarcord.

SP = Pușcariu, Sextil. 1906. Studii istroromâne, I. Texte. Bucharest: Institutul de Arte Grafice "Carol Göbl".

TC = Cantemir, Traian. 1959. Texte istroromâne. Bucharest: Editura Academiei.

Old Romanian *

CC $^{2} .1581$ = Coresi, Evanghelie cu învăţătură. Ed. by S. Puşcariu, Al. Procopovici: Diaconul Coresi, Carte cu învăţătură (1581), vol. I, Textul. Bucharest: Socec, 1914. (Braşov)

CM.1567 = Coresi, Molitvenic. Ed.: Coresi, Tâlcul evangheliilor şi molitvenic românesc, ed. by V. Drimba. Bucharest: Editura Academiei Române, 1998, 189-211. (Transylvania)

CV.1563-83= Codicele Voroneţean. Ed. by M. Costinescu. Bucharest: Editura Academiei, 1981, 229-400. (Moldova)

DVT.1679-99 = O traducere inedită a Vechiului Testament din secolul al XVI-lea. Ed. by C.-I. Dima. Bucharest: Editura Universități din București, 2009, 110-217. (Crișana, Bihor)

: FT.1571-5 = Fragmentul Todorescu (Carte de cântece). Ed. by I. Gheţie. Ed.: TR (1982): 336-43. (Transylvania, Cluj)

NT.1648 = Noul Testament. Alba Iulia: Reîntregirea, 1998. (Alba Iulia)

Prav.1581 =Pravila ritorului Lucaci. Ed. by I. Rizescu. Bucharest: Editura Academiei, 1971, 161-83. (Moldova, Putna Monastery)

Prav.1646 = Carte românească de învăţătură. Ed.: Carte românească de învăţătură. 1646, ed. by Colectivul pentru vechiul drept românesc condus de acad. A. Rădulescu. Bucharest: Editura Academiei, 1961, 33-106 (Adunarea izvoarelor vechiului drept românesc scris, 6).

(Moldova, Iași)

TR (1982) = I. Gheție (coord.), Texte românesti din secolul al XVI-lea. Bucharest: Editura Academiei.

ULM. 1725 = Grigore Ureche, Letopiseţul Ţării Moldovei. Ed. by P. P. Panaitescu. Bucharest: Editura de Stat pentru Literatură și Artă, 1955, 57-210. (Wallachia, original from Moldova)

* The corpus is based on a subset of the texts surveyed in Pană Pană Dindelegan's (2016) Syntax of Old Romanian. The abbreviation is followed by the year marking the date of the text. An interval is marked when the dating is not precise. Each example cited is followed by a reference to the folio $\left({ }^{\mathrm{r}} /{ }^{\mathrm{v}}\right)$ of manuscript/printed text from which it is excerpted. Where editors do not indicate the folios of the text, reference is made to the page of the edition. The localization of the texts is given at the end of the entry in round brackets. Our colleague Emanuela Timotin established the corpus and the citation conventions for the Syntax of Old Romanian; we would like to extend our gratitude to her.

\section{Notes}

1 There is a distinction between Northern and Southern Istro-Romanian, two mutually comprehensible yet distinct varieties which diverge in verb inflections and in other grammatical and phonological respects (see Kovačec 1984, especially pp. 550-54, and Maiden 2016, p. 91, a.o.); Northern Istro-Romanian is spoken to the north of Mount Učka (in the village of Žejane), while Southern Istro-Romanian is spoken in several villages and hamlets (Šušnjevica, Brdo, Noselo, etc.) to the south of Mount Učka. The grammatical properties relevant for the phenomena discussed in this paper are present both in the north and in the south; henceforth, by Istro-Romanian, we refer to all the possible varieties present on the territory.

2 When referring to empirical phenomena common to Croatian, Serbian, Bosnian, we use the conventional abbreviation BCS.

3 For Istro-Romanian, we have used the corpora collected in the 20th century by Sextil Puscariu, Leca Morariu, Traian Cantemir, Richard Sârbu and Vasile Frățilă, and August Kovačec; we have preserved the transcription conventions used in these sources. With respect to the other idioms discussed here (old Romanian and Croatian/BCS), most of the old Romanian examples used for illustration are taken from personal previous work (Dragomirescu 2013; Nicolae 2015, 2019b), and the Croatian examples are taken over from the reference literature.

4 As pointed out by one of the reviewers, since the settlement of the Istro-Romanians in Istria, the speakers of this idiom have been in contact with (standard) Croatian and the Čakavian variety (cf. Kalsbeek 1998 for a descriptive account of the Čakavian variety spoken in Orbanići). The fieldwork carried out in Istria (particularly in Šušnjevica, Žejane and Brdo, as well as in other places not traditionally inhabited by Istro-Romanians, but where Istro-Romanians have migrated-e.g., Brseč or Rijeka) in August-September 2021 (by a team of researchers which includes the authors of the present article) has revealed that the current Istro-Romanian speakers no longer speak the Čakavian variety, but rather standard Croatian. 
Auxiliary-licensed VP-ellipsis should be properly distinguished from verb-stranding VP-ellipsis (cf. Martins 1994, and see Goldberg 2005 for a comprehensive analysis), which is a different type of ellipsis.

6 There is empirical evidence for the fact that in old Romanian a low, $v$-oriented pronominal cliticization site is also residually active (cf. Nicolae 2019c for details); other Romance varieties also show instances of low cliticization (see Ledgeway and Lombardi 2005; Tortora 2014). However, none of the diagnostic features for this low site discussed by Nicolae (2019c) for old Romanian is found in Istro-Romanian, hence a potential low position for pronominal clitics in this idiom is excluded by default.

7 The abbreviation list for the source of the Istro-Romanian and old Romanian examples is present at the end of the article.

8 One of the reviewers raises the legitimate question of whether these adverbs raise to a high position (maybe due to information structure processes), which would imply that the position of the verb might not be that low. This hypothesis is discussed at length and discarded in Dragomirescu and Nicolae (2018) with reference to Istro-Romanian and in Nicolae (2019b) with respect to old Romanian; see also Schifano (2014), who addresses the issue of preverbal adverbials in standard modern Romanian, and shows that, besides interpretative effects, there are formal cues signalling adverb movement to the left periphery.

9 A larger basis of adverbials would have provided a finer-grained diagnosis of the level of verb movement; however, in this respect, we have been limited by the source material (a written, non-annotated corpus).

10 There is evidence for the fact that the Tobler-Mussafia law was residually active in old Romanian (Nicolae and Niculescu 2015).

11 Aux-to-C movement is found in old Spanish (Rivero 1994) and old Italian (Roberts 1994; Poletto 2014).

12 As an explanation, we can only speculate that clitic elements cannot themselves target a specifier position. The data of old Romanian and the residual instances of V-to-C in modern Romanian (conditional imprecations, positive imperatives and gerunds) empirically indicate that a clitic (a clitic auxiliary or a clitic adverbial) cannot itself undergo movement to C; clitic adverbials may incorporate into the structure of the moving verb and travel along with it to $C$, but they cannot undergo movement by themselves; auxiliaries do not incorporate and remain in the IP (see Nicolae 2019b, pp. 16-25 for details).

13 Notably, LHM with auxiliaries is also available in BCS/Croatian. The following paradigm (i) from Wilder and Ćavar (1994, p. 6) is illustrative in this respect; here, in the past perfect (ib) (made up of the combination of both a finite form and a participial form of the auxiliary BE (biti) plus the participle of the main verb), we see the auxiliary biti undergoing LHM (ib) (witness the ungrammaticality of $(9 \mathrm{c}))$ :

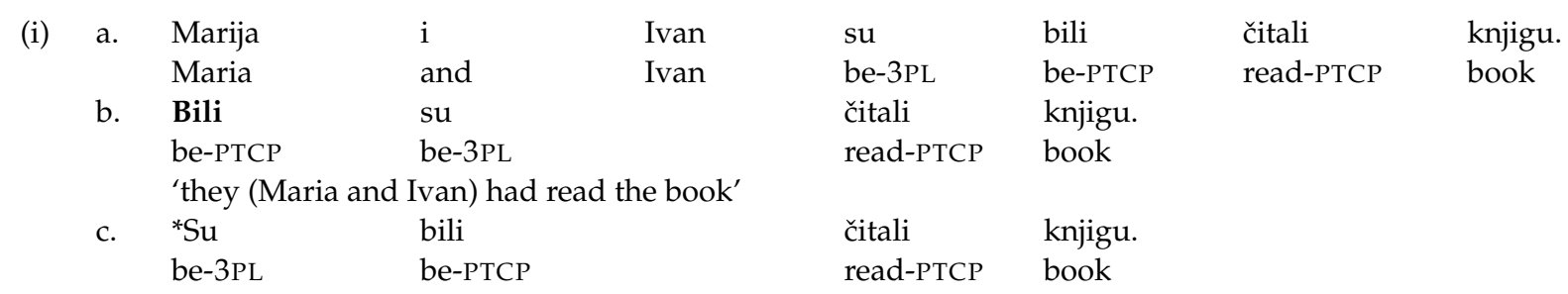

14 Morphophonological strength of the sort advocated here is also relevant in BCS/Croatian. Wilder and Ćavar (1994, p. 22) show that unstressed(/non-reduced) auxiliaries (i) block the application of LHM of lexical verbs in Croatian (ib), in opposition to their unstressed (reduced) counterparts (ii) (LHM in (iib)), with which they have in common identical tense properties.

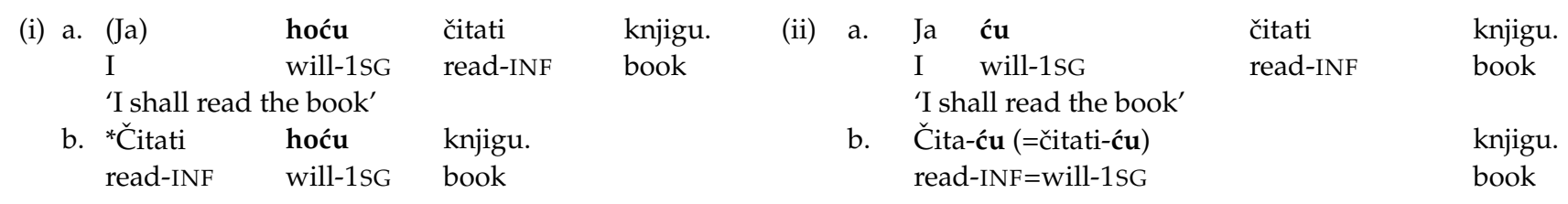

15 The notion "relaxed V2" was introduced by Ledgeway (2007) to characterize old Romance V2 grammars (except for Old French, which exhibits continental Germanic-type strict V2, cf. Roberts 1993). Thus, in these varieties, the verb in finite matrix clauses is required to move to $\mathrm{C}$, this movement operation being "generally, though not invariably, accompanied by a further movement rule which fronts one (or more) salient constituent(s) to a preverbal position" (Ledgeway 2007, p. 122).

IRR stands for 'irrealis'.

Fischer (forthcoming) focuses only on syntax-information structure phenomena (stylistic fronting and clitic doubling) in a contact setting, but clearly stresses that her account extends to the other interface (the syntax-phonology/prosody interface) as well.

\section{References}

Alboiu, Gabriela, and Virginia Motapanyane. 2000. The generative approach to Romanian grammar: An overview. In Comparative Studies in Romanian Syntax. Edited by Virginia Motapanyane. Amsterdam: Elsevier, pp. 1-48.

Authier, Marc. 2012. Ellipsis as movement and silence: Evidence from French. University of Pennsylvania Working Papers in Linguistics. 18. Available online: http:/ / repository.upenn.edu/cgi/viewcontent.cgi?article=1207\&context=pwpl (accessed on 1 November 2021). 
Avram, Larisa. 1999. Auxiliaries and the Structure of Language. Bucharest: Editura Universităţii din Bucureşti.

Čamdžić, Amela, and Richard Hudson. 2007. Serbo-Croat-Bosnian clitics and word grammar. Research in Language 5: 5-50. [CrossRef]

Carabulea, Elena. 2007. Predicatul. In Sintaxa limbii române în secolele al XVI-lea-al XVIII-lea. Edited by Mioara Avram. Bucharest: Editura Academiei Române, pp. 42-52.

Caragiu Marioțeanu, Matilda. 1975. Compendiu de dialectologie română. Bucharest: Editura Științifică și Enciclopedică.

Cinque, Guglielmo. 1999. Adverbs and Functional Heads. Oxford: Oxford University Press.

Clark, Robin, and Ian Roberts. 1993. A computational approach to language learnability and language change. Linguistic Inquiry 24: 299-345.

Cornilescu, Alexandra. 2000. The double subject construction in Romanian. In Comparative Studies in Romanian Syntax. Edited by Virginia Motapanyane. Amsterdam: Elsevier, pp. 83-133.

Coteanu, Ion. 1957. Cum dispare o limbă: Istroromâna. Bucharest: Societatea de Științe Istorice și Filologice.

Dobrovie-Sorin, Carmen. 1994. The Syntax of Romanian. Berlin: Mouton de Gruyter.

Dragomirescu, Adina. 2013. O schimbare parametrică de la româna veche la româna modernă în sintaxa formelor verbale compuse cu auxiliar. Limba română 62: 225-239.

Dragomirescu, Adina, and Alexandru Nicolae. 2016. O trăsătură sintactică a românei vechi păstrată în istroromână: Interpolarea. Limba română 65: 454-464.

Dragomirescu, Adina, and Alexandru Nicolae. 2018. Syntactic archaisms preserved in a contemporary romance variety: Interpolation and scrambling in old Romanian and Istro-Romanian. In Comparative and Diachronic Perspectives on Romance Syntax. Edited by Gabriela Pană Dindelegan, Adina Dragomirescu, Irina Nicula and Alexandru Nicolae. Newcastle upon Tyne: Cambridge Scholars Publishing, pp. 85-115.

Dragomirescu, Adina, and Alexandru Nicolae. 2020. Particular features of Istro-Romanian pronominal clitics. Studia UBB Philologia 65: 147-58. [CrossRef]

Filipi, Goran. 2002. Istrorumunjski lingvistički atlas/Atlasul Lingvistic Istroromân/Atlante Linguistico Istrorumeno. Pula: Znanstvena udruga Mediteran.

Fischer, Susann. forthcoming. Language contact and the development of Judeo-Spanish syntax. In New Perspectives on the Language(s) of the Sephardim. Edited by Frank Savelsberg and Laura Minervini. Boston and Leiden: Brill, In press.

Geană, Ionuț. 2017. On the use of the compound past in Istro-Romanian. In Sintaxa ca mod de a fi. Omagiu Gabrielei Pană Dindelegan, la aniversare. Edited by Adina Dragomirescu, Alexandru Nicolae, Camelia Stan and Rodica Zafiu. Bucharest: Editura Universității din București, pp. 209-14.

Giusti, Giuliana, and Iulia Zegrean. 2015. Syntactic protocols to enhance inclusive cultural identity. A case study on Istro-Romanian clausal structure. Quadermi di linguistica e studi orientali/Working papers in linguistics and oriental studies 1: 117-38.

Goldberg, Lotus. 2005. Verb-Stranding VP Ellipsis: A Cross-Linguistic Study. Ph.D. dissertation, McGill University, Montreal, QC, Canada.

Harizanov, Boris. 2016. Head movement to specifier positions in Bulgarian participle fronting. Paper presented at the 90th Annual Meeting of the Linguistic Society of America (LSA 90), Washington, DC, January 7-10.

Hickey, Raymond. 2010. Language contact: Reassessment and reconsideration. In The Handbook of Language Contact. Edited by Raymond Hickey. Malden: Wiley-Blackwell, pp. 1-28.

Hill, Virginia, and Gabriela Alboiu. 2016. Verb Movement and Clause Structure in Old Romanian. Oxford: Oxford University Press.

Hopper, Paul J., and Elizabeth Closs Traugott. 2003. Grammaticalization. Cambridge: Cambridge University Press, vol. 1, p. 1993.

Hurren, Anthony. 1999. Istro-Romanian—A Functionalist Phonology and Grammar. Oxford: MSS. First published in 1981.

Kalsbeek, Janneke. 1998. The Čakavian Dialect of Orbanići near Žminj in Istria. Studies in Slavic and general linguistics 25. Amsterdam and Atlanta: Rodopi.

Kayne, Richard S. 1991. Romance clitics, verb movement, and PRO. Linguistic Inquiry 22: 647-86.

Kovačec, August. 1966. Quelques influences croates dans la morphosyntaxe istroroumaine. Studia Romanica et Anglica Zagrabiensia 21-22: 57-75.

Kovačec, August. 1968. Observations sur les influences croates dans la grammaire istroroumaine. La Linguistique 1: 79-115.

Kovačec, August. 1971. Descrierea istroromânei Actuale. București: Editura Academiei.

Kovačec, August. 1984. Istroromâna. In Tratat de dialectologie românească. Edited by Valeriu Rusu. Craiova: Scrisul Românesc, pp. 550-91.

Kovačec, August. 1998. Istrorumunjsko-hrvatski rječnik (s gramatikom i tekstovima). Pula: Mediteran.

Ledgeway, Adam. 2007. Old Neapolitan word order: Some initial observations. In Languages of Italy: Histories and Dictionaries. Edited by Anna Laura Lepschy and Arturo Tosi. Ravenna: Longo Editore, pp. 119-46.

Ledgeway, Adam. 2012. From Latin to Romance: Morphosyntactic Typology and Change. Oxford: Oxford University Press.

Ledgeway, Adam. 2015. Romance auxiliary selection in light of Romanian evidence. In Diachronic Variation in Romanian. Edited by Gabriela Pană Dindelegan, Rodica Zafiu, Adina Dragomirescu, Irina Nicula, Alexandru Nicolae and Louise Esher. Newcastle upon Tyne: Cambridge Scholars Publishing, pp. 3-34.

Ledgeway, Adam. 2016. Functional categories. In The Oxford Guide to the Romance Languages. Edited by Adam Ledgeway and Martin Maiden. Oxford: Oxford University Press, pp. 761-71. 
Ledgeway, Adam, and Alessandra Lombardi. 2005. Verb movement, adverbs, and clitic positions in Romance. Probus 17: 77-101. [CrossRef]

Maiden, Martin. 2016. Romanian, Istro-Romanian, Megleno-Romanian, and Aromanian. In The Oxford Guide to the Romance Languages. Edited by Adam Ledgeway and Martin Maiden. Oxford: Oxford University Press, pp. 91-125.

Martins, Ana Maria. 1994. Enclisis, VP-deletion and the nature of Sigma. Probus 6: 173-205. [CrossRef]

Migdalski, Krzysztof. 2009. On two types of Wackernagel cliticization in Slavic. In Formal Approaches to Slavic Linguistics: The Yale Meeting 2008. Edited by Jodi Reich, Maria Babyonyshev and Daria Kavitskaya. Arbor: Michigan Slavic Publications, pp. 147-62.

Mišeska Tomić, Olga. 1996. The Balkan Slavic clausal clitics. Natural Language E Linguistic Theory 14: 811-72.

Nicolae, Alexandru. 2015. Ordinea constituenților în limba română: O perspectivă diacronică. Structura propoziției și deplasarea verbului. Bucharest: Editura Universității din București.

Nicolae, Alexandru. 2019a. The Licensing of Nominal and Verbal Ellipsis in Romanian. Bucharest: Editura Universității din București.

Nicolae, Alexandru. 2019b. Word Order and Parameter Change in Romanian. Oxford: Oxford University Press.

Nicolae, Alexandru. 2019c. O poziție de cliticizare joasă în limba română veche. In Variație diacronică și diatopică. Note gramaticale. Edited by Gabriela Pană Dindelegan, Adnana Boioc Apintei and Blanca Croitor. Bucharest: Editura Universității din București, pp. 143-57.

Nicolae, Alexandru, and Dana Niculescu. 2015. On clitics and clitic clusters in Old Romanian: Verb movement and the Tobler-Mussafia Law. Revue Roumaine de Linguistique 60: 223-41.

Pană Dindelegan, Gabriela, ed. 2016. The Syntax of Old Romanian. Oxford: Oxford University Press.

Poletto, Cecilia. 2014. Word Order in Old Italian. Oxford: Oxford University Press.

Poole, Geoffrey. 2007. Interpolation and the left periphery in Old Spanish. In Newcastle and Northumbria Working Papers in Linguistics 13: 188-216.

Popovici, Ioan. 1914. Dialectele române din Istria. Partea I (Referinţele sociale şi gramatica). Halle: Editura Autorului.

Puşcariu, Sextil. 1926. Studii istroromâne. II. Introducere-Gramatică-Caracterizarea dialectului istroromân. Bucharest: Institutul de Arte Grafice "Carol Göbl".

Rivero, María-Luisa. 1992. Patterns of V0-raising in long head movement and negation: Serbo-Croatian vs. Slovak. In Syntactic Theory and Basque Syntax. Edited by Joseba A. Lakarra and Jon Ortiz de Urbina. Donostia: Gipuzkoako Foru Aldundia, pp. $365-86$.

Rivero, María-Luisa. 1994. Clause-structure and V-movement in the languages of the Balkans. Natural Language E Linguistic Theory 12: 63-120.

Rivero, Maria-Luisa. 1997. On two locations for complement-clitic pronouns: Serbo-Croatian, Bulgarian and Old Spanish. In Parameters of Morphosyntactic Change. Edited by Ans van Kemenade and Nigel Vincent. Cambridge: Cambridge University Press, pp. 170-206.

Rizzi, Luigi. 1997. The fine structure of the left periphery. In Elements of Grammar. Edited by Liliane Haegeman. Dordrecht: Kluwer Academic Publishers, pp. 281-337.

Roberts, Ian. 1993. Verbs and Diachronic Syntax: A Comparative History of English and French. Dordrecht: Kluwer.

Roberts, Ian. 1994. Two types of head movement in Romance. In Verb Movement. Edited by David Lightfoot and Norbert Hornstein. Cambridge: Cambridge University Press, pp. 207-42.

Roberts, Ian, and Anna Roussou. 2003. Syntactic Change: A Minimalist Approach to Grammaticalization. Cambridge: Cambridge University Press.

Sârbu, Richard, and Vasile Frățilă. 1998. Dialectul istroromân. Texte și glosar. Timișoara: Editura Amarcord.

Săvescu Ciucivara, Oana. 2011. A Syntactic Analysis of Pronominal Clitic Clusters in Romance: The View from Romanian. Bucharest: Editura Universităţii din Bucureşti.

Schifano, Norma. 2014. (Un)marked patterns of verb-movement: The case of Romanian. In Limba română: Sincronie şi diacronie în studiul limbii române, vol. 1: Gramatică. Fonetică şi fonologie. Istoria limbii române. Edited by Rodica Zafiu, Adina Dragomirescu and Alexandru Nicolae. Bucharest: Editura Universităţii din Bucureşti, pp. 191-201.

Schifano, Norma. 2018. Verb Movement in Romance: A Comparative Study. Oxford: Oxford University Press.

Schütze, Carson T. 1994. Serbo-Croatian second position clitic placement and the phonology-syntax interface. MIT Working Papers in Linguistics 21: 373-473.

Stjepanović, Sandra. 1998. On the Placement of Serbo-Croatian Clitics: Evidence from VP-Ellipsis. Linguistic Inquiry 29: 527-37. [CrossRef]

Stojanović, Danijela. 1997. Object shift in Serbo-Croatian. In Clitics, Pronouns and Movement. Edited by James R. Black and Virginia Motapanyane. Amsterdam: John Benjamins Publishing Company, pp. 301-19.

Thoms, Gary. 2010. “"Verb floating” and VP-ellipsis: Towards a movement account of ellipsis licensing'. Linguistic Variation Yearbook 10: 252-97. [CrossRef]

Timotin, Emanuela. 2016. Presenting the corpus: Typologizing, dating, and locating the texts. In The Syntax of Old Romanian. Edited by Gabriela Pană Dindelegan and Martin Maiden. Oxford: Oxford University Press, pp. 1-7.

Tortora, Christina. 2014. Clausal domains and clitic placement generalizations in Romance. In Romance Languages and Linguistic Theory 2012. Edited by Karen Lahousse and Stefania Marzo. Amsterdam: John Benjamins, pp. 1-36.

Vicente, Luis. 2007. The Syntax of Heads and Phrases: A Study of Verb (Phrase) Fronting. Ph.D. dissertation, 2007, Leiden University, Leiden, The Netherlands, LOT Dissertations, Utrecht, The Netherlands. 
Vrzić, Zvjezdana, and Robert Doričić. 2014. Language contact and stability of basic vocabulary: Croatian words for body parts in Vlashki/Zheyanski (Istro-Romanian). Fluminensia 26: 105-22.

Wilder, Chris, and Damir Ćavar. 1994. Long head movement? Verb movement and cliticization in Croatian. Lingua 93: 1-58. [CrossRef]

Zamfir, Dana-Mihaela. 2007. Morfologia verbului în dacoromâna veche (secolele al XVI-lea-al XVII-lea). Bucharest: Editura Academiei Române, vol. 2.

Zegrean, Iulia. 2012. Balkan Romance: Aspects on the Syntax of Istro-Romanian. Ph.D. dissertation, Università Ca' Foscari, Venezia, Italy. 